\title{
Nonfinancial debt and economic growth in euro-area countries
}

\author{
Marta Gómez-Puig ${ }^{a^{*}}$, Simón Sosvilla-Rivero \\ ${ }^{a}$ Department of Economics and Riskcenter, Universitat de Barcelona. \\ 08034 Barcelona, Spain \\ ${ }^{\mathrm{b}}$ Complutense Institute for International Studies, Universidad Complutense de Madrid. \\ 28223 Madrid, Spain
}

March 2018

\begin{abstract}
In this paper, we analyse the effects of all sources of nonfinancial debt (household, corporate as well as government) accumulation on economic growth in ten euro-area countries during the 1980-2015 period. To this end, we make use of three models (a baseline, an asymmetric and a threshold model) based on the empirical growth literature augmented by debt. By exploring the time series dimension in order to properly account for the historical experience of each country in the sample, we aim to detect potential heterogeneities in the relationship across euro-area economies. Our findings suggest that while public debt thresholds are higher in peripheral than in central countries, private debt thresholds are higher in core euro-area countries. Moreover, while a reduction in nonfinancial corporations' and public debt has a negligible effect on growth, the response is very relevant in the case of households but clearly differs across countries (the average impact being higher in peripheral than in central countries). Therefore, according to our results, peripheral countries especially should be aware of the adverse consequences of private debt accumulation and a reduction in households' debt in those countries may be crucial to stimulate consumption and growth.
\end{abstract}

Keywords: Public debt, household debt, nonfinancial corporate debt, economic growth, heterogeneity, euro area, peripheral euro -area countries, central euro-area countries.

JEL Classification Codes: C22, D12, F33, H63, O16, O40, O52

\footnotetext{
* Corresponding author. Tel.: +34 934020113; fax: +34 934039082.

E-mail addresses: marta.gomezpuig@ub.edu (M. Gómez-Puig), sosvilla@,ccee.ucm.es (S. Sosvilla-Rivero)
} 


\section{Introduction}

The perspective provided by the period of more than eight years since the start of the European Economic and Monetary Union (EMU) sovereign debt crisis in late 2009 highlights the fact that its origin goes beyond fiscal imbalances in euro-area countries. Indeed, the main causes of the debt crisis in Europe vary according to country; they reflect an important interconnection between public and private debt (see Singh et al., 2016). Yet one of the lessons of the recent sovereign crisis in the euro-area is that in some countries such as Ireland or Spain there was next to nothing in the key indicators of public debt that suggested the imminent catastrophe; the build-up of financial fragility occurred in private sector balance sheets ${ }^{1}$.

The increase recorded by total nonfinancial debt in euro-area countries during the past three decades has been very significant, not only in the public sector (governments), but in the private sector (households and nonfinancial corporations) as well. However, while the unprecedented increase in public debt across EMU countries has raised serious concerns among economists about both its sustainability and its impact on economic growth ${ }^{2}$ [see, e.g., Aldici et al. (2016), Dreger and Reimers (2013) or Teles and Mussolini (2014)], they have taken a more nuanced position on the risks of private debt accumulation, despite its magnitude. Schularick (2013) points out that this attitude can be attributed to the incentive problems that may arise when governments, as opposed to private households and companies, borrow; as private sector borrowers act in their informed self-interest, they are assumed to bear the consequences of their actions. Nevertheless, all forms of nonfinancial debt, when they are high and moving upwards, are sources of justifiable concern. In particular, the negative implications of excessive private debt (a "debt overhang"3) for growth and financial stability are well documented in the literature, underscoring the need for private sector deleveraging in some countries.

In a series of recent papers, some authors [see, e.g., Schularick and Taylor (2012) and Jordà et al. (2016a)] demonstrate that high debt levels in the private sector are not only a good

\footnotetext{
1 The important role played by private debt, especially by financial debt, in EMU sovereign debt crisis in some countries was already stressed by Gómez-Puig and Sosvilla-Rivero (2013). However, banks' debt is not included in this paper since, as these authors point out, it is rather difficult to build up this variable avoiding all the effects of intermediation. So, following the usual criteria used by both international organizations (IMF, OECD) and private-sector analysts (research departments of financial institutions), this paper will focus on the effects of all sources of nonfinancial debt accumulation (household, corporate as well as government) on economic growth in ten euro-area countries during the 1980-2015 period.

${ }^{2}$ On average, public debt reached levels about $100 \%$ of Gross Domestic Product (GDP) - its highest level in 50 years by the end of 2013 .

3 A situation in which a borrower's debt service exceeds its future repayment capacity.
} 
predictor of financial crises, but also a key determinant of the intensity of the ensuing recession. Moreover, high private debt levels can also hamper growth even in the absence of a financial crisis, since the accumulation of debt involves risk (International Monetary Fund, 2016a). As debt levels increase, borrowers' ability to repay becomes progressively more sensitive to falls in income and sales as well as to increases in interest rates. In fact, high private debt can have a substantial adverse impact on macroeconomic performance and stability, as it hinders the ability of households to smooth their consumption and affects corporations' investments. In addition, elevated debt levels can create vulnerabilities or amplify and transmit macroeconomic and asset price shocks throughout the economy [see, e.g., Sutherland and Hoeller (2012) or Fisher (1931) whose theory of business cycles stressed that private over-indebtedness played a key role in generating severe recessions (and even depressions)]. Finally, spillovers from private balance sheets to the public sector due to government interventions (either direct in the form of targeted programs for debt restructuring, or indirect through the banking sector), may weaken the fiscal position or increase interest rates. All the above factors may compromise public debt sustainability (see Jarmuzek and Rozenov, 2017) ${ }^{4}$.

Despite the relevance of this issue, after an economic and debt crisis that even called into question the stability of the euro and which highlighted that, in some countries, there was barely nothing in the main indicators of government debt that indicated the impending crisis (financial instability had its origin in the private sector), the literature examining the effects of high private debt levels on euro-area countries' economic growth is very limited; the papers available do not focus exclusively on EMU countries but analyse the impact of private debt on economic growth in a broader group of economies, including some euroarea members. In particular, Cecchetti et al. (2011) analysed the impact of both private and public debt on 18 OECD countries' growth (10 belonging to the EMU), and Lombardi et al. (2017) examined the effects of households' debt on economic growth in 54 economies (11 euro-area countries). Conversely, more research has focused on the impact of government debt on EMU countries' growth [Baum et al. (2013), Checherita-Westphal and Rother (2012) or Gómez-Puig and Sosvilla-Rivero (2017) to name just a few].

Hence, this paper aims to fill the gap in the literature by assessing the effect of all sources of nonfinancial debt, i.e., not only governments' debt, but also households' and

\footnotetext{
${ }^{4}$ These authors also provide a quantitative assessment of the gaps between current and sustainable levels of private debt,
} identifying the key factors that drive excessive borrowing. 
nonfinancial corporations, ${ }^{5}$, on economic growth in ten euro-area countries. To this end, we use a methodology that builds on Gómez-Puig and Sosvilla-Rivero (2017) and explicitly takes into account the possible heterogeneity (see, e.g., Erberhart and Presbitero, 2015 or Chudick et al., 2017) in the relationship between all forms of nonfinancial debt and growth across euro-area countries.

We apply this methodology to an examination of whether the impact of a debt increase on economic growth might differ not only depending on the source of debt, but also on the idiosyncrasies of each EMU country. Hence, our paper tries to go forward the scarce literature that has examined the impact of private debt on economic growth by means of panel data techniques and obtained average results for all the countries in their study [Cecchetti et al. (2011) or Lombardi et al. (2017)].

The rest of the paper is organized as follows. Section 2 explains the rationale for our analysis on the basis of the results of some preliminary descriptive analyses of the evolution of public and private indebtedness in euro-area countries. Section 3 provides a literature review. Section 4 introduces the analytical framework. Section 5 presents the data used in the analysis and its time series properties. Section 6 offers our empirical models. Empirical results are presented in Section 7. Finally, some concluding remarks and policy implications are provided in Section 8.

\section{Private and public indebtedness evolution in EMU countries}

As stated above, the past three decades have witnessed a remarkable rise in the total nonfinancial debt in euro-area economies. Therefore, in what follows, we provide some descriptive analyses of the behaviour of nonfinancial debt during the 1980-2015 period in EMU countries: specifically, the evolution of private (households and nonfinancial corporations), public and total nonfinancial debt-to-GDP during this period in 10 euroarea countries ${ }^{6}$ (both central -Austria, Belgium, Finland, France, Germany and the Netherlands - and peripheral - Greece, Italy, Portugal and Spain) ${ }^{7}$ jointly with its average value is shown in Figure 1.

[Insert Figure 1 around here]

\footnotetext{
5 As stated before, we do not include banks' debt in the analysis because of the difficulties in the construction of this variable in order to avoid all the effects of intermediation.

${ }^{6}$ Ireland is not included in this analysis because the Central Bank of Ireland's Quarterly Financial Accounts only provide data from the first quarter of 2002.

${ }^{7}$ This distinction between European central and peripheral countries has been extensively used in the empirical literature.
} 
Figure 1 contains some revealing data. Total nonfinancial debt as a percentage of GDP, as well as its components, rose steadily for much of the 1980-2015 period. Starting at a relatively modest 147 percent of GDP in 1980, 36 years later this figure had reached 304 percent of GDP in EMU countries. In this increase, public debt accounts for 160 percentage points and private debt for 90 percentage points. However, the average ratio of indebtedness in the private sector $(146 \%)$ is much higher (it represents around two thirds of the total debt ratio) than that in the public sector $(77 \%)$ throughout the period. The evolution of the two components of private debt considered (households and nonfinancial corporations) is presented in Figure 2.

\section{[Insert Figure 2 around here]}

Figure 2 suggests that it is nonfinancial corporations rather than households that cause the high debt levels registered by the private sector during the period examined (companies' average debt ratio, $98 \%$, is more than double that of families, $48 \%$ ). Nonetheless, the growth rate of the debt during the period is higher for households $(159 \%)$ than for nonfinancial corporations $(65 \%)$.

Therefore, the rate of increase of the debt-to-GDP ratio during the 1980-2015 period is very high not only for the public sector but also for households ${ }^{8}$ (close to $160 \%$ in both cases). Moreover, although nonfinancial corporations' debt records a lower rate of growth throughout the period, it represents around $44 \%$ of total nonfinancial debt, followed by the public sector $(35 \%)$ and households $(21 \%)$.

Tables $1 \mathrm{a}$ and $1 \mathrm{~b}$ present the evolution of debt-to-GDP ratios for households, firms and governments during the 1980-2015 period for the EMU central and peripheral countries included in our sample.

[Insert Tables $1 \mathrm{a}$ and $1 \mathrm{~b}$ around here]

Table $1 \mathrm{a}$ indicates that, in central countries, the highest increase in public debt took place in the 1980s and 1990s (before the launch of the euro), while during the decade preceding the onset of the crisis (from 1999 until 2009) the highest rate of growth was recorded by private debt (both households and nonfinancial corporations) rather than public debt.

\footnotetext{
${ }^{8}$ Household debt growth has normally been explained in the literature as a rational response of forward looking agents to hump-shaped time earning profiles or to temporary deviations of income from its long-run trend. So, mainstream theories can encompass the concept of excessive indebtedness only supposing that agents' maximizing behaviour results from a less than perfect rationality and foresight (see, e.g., Barnes and Young, 2003).
} 
A similar pattern is observed in most peripheral countries (see Table 1b), where public debt presents a noticeable upward trend during the two decades preceding the introduction of the common currency. This led to the high values registered by the sovereign debt-to-GDP ratio in 2009 coinciding with the outbreak of the crisis $(120 \%, 106 \%$ and $80 \%$ in Greece, Italy and Portugal respectively) ${ }^{9}$. However, during the first ten years of monetary union, the rate of increase of private debt also overtook that of the public sector in peripheral countries. In particular, households' debt registered a rate of increase that ranges from $54 \%$ in Portugal to 223\% in Greece, while nonfinancial corporations' debt recorded its highest rate of increase in Spain (83\%), followed by Greece, Portugal and Italy.

Therefore, during the 2000s, on the eve of the recent sovereign debt crisis caused by the globalization of banking, rapid financial liberalization and a period of easy access to credit, nonfinancial private debt increased substantially in EMU Member States (both central and peripheral). The situation had become clearly unsustainable by the onset of the financial crisis. It is noticeable that during the first ten years of the euro, not only did exchange risk disappear, but credit risk also fell progressively as markets perceived sovereign markets as a single unit, dismissing macroeconomic imbalances within euro-area countries and the possibility that governments might default ${ }^{10}$. As a result, along with the downward trend registered by sovereign bond yields, long-term interest rates also converged to very low values, fostering a credit expansion in the nonfinancial private sector ${ }^{11}$. So, in 2015 about two-thirds of total EMU countries' nonfinancial debt had its origin in the private sector. It is worth noting that a similar pattern has been registered by non-EMU countries. According to the International Monetary Fund (2016a), the global gross debt of the nonfinancial sector - comprising the general government, households, and nonfinancial firms - has more than doubled in nominal terms since the turn of the century, reaching $\$ 152$ trillion in 2015 - i.e., 225 per cent of world GDP. About two-thirds of this debt consists of liabilities of the private sector.

In addition, Table $1 \mathrm{~b}$ also indicates that private debt also recorded an important surge in some EMU peripheral countries, not only during the 2000s but also during the two decades

\footnotetext{
${ }^{9}$ It is noticeable that in other EMU peripheral countries such as Spain, with a debt-to-GDP ratio in 2009 close to $50 \%$, considerably below the Stability and Growth Pact (SGP) ceiling, it seems that it was private rather than public debt that triggered the crisis.

${ }_{10}$ Nevertheless, with the financial crisis the picture changed completely and sovereign long-term interest rates rose sharply. Indeed, the crisis put the spotlight on the macroeconomic and fiscal imbalances within EMU countries which had largely been ignored during the 1999-2009 period (see Gómez-Puig et al., 2014).

${ }^{11}$ Alves and Pereira (2017) examine the dramatic indebtedness increase among households in Portugal, detecting a structural break around 1992, which may correspond to the signing of the Maastricht Treaty which ultimately led to this decline in interest rates and consequently the increase in indebtedness.
} 
before the start of the monetary union. In particular, during the 1980s the rate of growth of households' debt was 225\% in Italy and 65\% in Spain, while it increased notably in Portugal and Greece (193\% and 85\% respectively) during the 1990s. In that decade, firms' debt also registered notable rises in Portugal and Italy (104\% and 45\% respectively). Finally, of course, expost, the severe financial crisis and economic recession would damage public finances via crashing revenues and rising cyclical expenditures, and consequently fuelling the public debt increase. Hence, during the 2009-2012 period, the public sector registered the highest rise in debt levels in all peripheral countries, with especially high increases in Spain (66\%) and in Portugal (56\%), while private debt began a deleveraging trend.

All in all, some interesting insights can be drawn from Figures 1 and 2 and Tables $1 \mathrm{a}$ and $1 \mathrm{~b}$, and they in fact motivate the analysis presented in this paper. First, during the last three decades debt upward trend was significant not only in the public sector but in the private sector as well, providing one reason why economists and policy makers should take private sector indebtedness as seriously as public indebtedness. Second, private sector credit growth, not public debt accumulation, provides the key to understanding the build-up of the sovereign debt crisis in some euro-area countries. Third, the tendency to socialize the losses from private sector financial crisis has grown; they have become a key risk factor for public finances and have fostered the tight link between the private credit cycle and the fiscal cycle. Fourth, since high debt levels in the private sector are a determining element of the strength of the following recession (see Jordà et al., 2016a), examining their nexus with economic growth emerges as a key topic that deserves economists' attention (especially in euro-area countries that faced a fierce banking, sovereign and economic crisis). Finally, today's unprecedented indebtedness levels (in both the public and the private sector) in EMU countries should be a matter of concern as long as the expected normalization in the future European Central Bank's monetary policy could push up long-term interest rates. In that case, interest expenses on the debt would start to increase borrowers' risk and eventually lead to a debt overhang, with the subsequent adverse effect on economic growth.

We should stress that Ireland's debt evolution is not included in Figures 1 and 2 and Tables $1 \mathrm{a}$ and $1 \mathrm{~b}$ because private debt data are only available in this country from the first quarter of 2002 onwards. So, despite the relevance of private debt in the Irish economy and sovereign crisis (see Lydon and McIndoe-Calder, 2017), due to these data restrictions, in 
this paper we analyse the impact of nonfinancial debt (households, nonfinancial corporations and governments) on economic growth in ten EMU countries (excluding Ireland from the analysis) during the $1980-2015$ period $^{12}$.

\section{Literature review}

Until the recent crisis, economists worried mainly about public debt, not about private debt. The warning signs of increased private leverage in the run-up to the crisis of 2008 were largely ignored. However, as shown in Figures 1 and 2, the increase in euro-area debt levels during the last 36 years was due to the behaviour not only of the public sector, but of the private sector as well, in particular of households. Moreover, firms' debt, which shows the highest share of total debt throughout the period, represents an important potential burden for the recovery of the economies. As it turns out, in 2015 only about one third of total debt in EMU countries corresponds to public debt accumulation. In other words, the overwhelming share of the debt increase has been due to higher borrowing by households and nonfinancial companies.

Therefore, economists should not disregard private sector leveraging; in fact they should pay as much attention to it as they do to public debt. The literature on this topic is still scarce, but not non-existent. One strand of the literature has focused on the relationship between the different forms of debt. Angeletos et al. (2016) highlighted that government debt expansions significantly influence households' financial condition; investigating the impact of government debt on corporate financing decisions, Demirci et al. (2017) found a negative relation between government debt and corporate leverage using data on 40 countries during the 1990-2014 period; and Uusküla (2016) examined the relationship between more than 30 macroeconomic variables and debt-to-GDP ratios for household, nonfinancial corporation and aggregate debt in a panel of European Union countries.

Another strand of literature examines the effects that the generalized and necessary deleveraging process currently taking place in the private sector may have on economic activity [see Crowe et al. (2011), Ruscher and Wolff (2013), Cuerpo et al. (2015) or Kuvshinov et al. (2016)]. Other authors (see, e. g., Bernardini and Peersman, 2015; Klein, 2016) have shown that the effects of fiscal consolidations crucially depend on the level of

12 The sample period (1980-2015) has also been determined by private debt data availability. 
private indebtedness (mostly household leveraging), whereas the state of the business cycle and the level of public debt play only a minor role in the effectiveness of fiscal policy ${ }^{13}$.

Finally, some recent contributions have pointed to the important role of private debt for the propagation and amplification of shocks, since a high level of indebtedness may render the economy more vulnerable to negative shocks than otherwise. Mian and Sufi (2017) showed that an increase in the household debt to GDP predicts lower subsequent GDP growth and higher unemployment; Jordà et al. (2016b) found that more mortgage-intensive credit expansions tend to be followed by deeper recessions and slower recoveries, but that this effect is not present for non-mortgage credit booms ${ }^{14}$; using data for 31 OECD and 20 emerging market countries Randveer et al. (2011) found that a higher level of private debt before a recession is correlated with lower economic growth after the economic slowdown has finished; using microeconomic data for the United States Garriga et al. (2017) reported that most forms of private debt (mortgages, credit card debt, and auto loans) had significant boom-bust cycles; and Guerini et al. (2017) investigated the causal effects of public and private debts on U.S. output dynamics.

Nonetheless, the literature centred on the effects of high private debt levels on euro-area countries' economic growth is very limited and only includes papers that, instead of focusing on EMU economies, analyse the impact in a broader group that includes some euro-area countries by means of panel data techniques (obtaining average results for the whole group of countries under study). Therefore, due to the high relevance of private indebtedness in the build-up of the European sovereign and financial crisis, this paper aims to fill the gap existing in the literature by examining the effect of all sources of nonfinancial debt (i.e., not only public, but also private) on economic growth in a sample of ten EMU countries which have recently endured a severe financial and economic crisis. Our objective is to analyse, not only whether the effect of debt accumulation depends on the source of debt (households, companies or governments), but also on the idiosyncrasies of the different countries (i.e., whether there exist heterogeneities in the relationship across EMU economies). Hence, we will follow the recent literature on the debt-growth nexus [see Ghosh et al. (2013), Pescatori et al. (2014), Edberhardt and Presbitero (2015), Markus and

\footnotetext{
13 Additionally, Klein and Winkler (2017) provide empirical evidence supporting the view that fiscal consolidations lead to a strong and persistent increase in income inequality during periods of private debt overhang.

14 For example, it is well documented that in the U.S. during the financial crisis, the households that took subprime loans were much more prone to foreclosure and bankruptcy (Li and White, 2009).
} 
Rainer (2016), Chudik et al. (2017) or Gómez-Puig and Sosvilla-Rivero (2017) $]^{15}$ which has pointed out that, since the capacity to tolerate high levels of debt may depend on a number of country-specific characteristics (the degree of their financial deepening, their track records in meeting past obligations, the nature of their political economic systems, the debt trajectory, the macro and institutional framework, etcetera), the relationship between debt and economic growth may present heterogeneities across countries and it is therefore very important to take account of them. Indeed, both Erberhart and Presbitero (2015) and Chudick et al. (2017), who examine the relationship in a large sample of countries (both advanced and developing economies), find no evidence for a universally applicable threshold effect in the relationship between public debt and economic growth, while Gómez-Puig and Sosvilla-Rivero (2017) also suggest that the harmful impact of a government debt change on growth does not occur beyond the same threshold and with the same intensity across EMU countries.

So, given the heterogeneities in the relationship between public debt and economic growth in the ten euro-area countries under study that have already been found, that private debt trajectory also presents clear differences across those countries during the 1980-2015 period (see Tables 1), and that a wide literature [see, e.g., Auray and Eyquem (2017), Unger (2017), Schmitz and von Hagen (2011), Kalemi-Ozcan et al. (2010) and Spiegel (2009)] has examined the heterogeneities and imbalances across EMU economies, that were observed after the common currency was adopted, since they contributed to the outbreak of the crisis $^{16}$, in this paper we will examine whether the effects of all types of nonfinancial debt (governments, companies and households) on economic growth differ across euro-area countries because we think that this analysis may teach us more about the relationship between nonfinancial debt and growth than the average relationships that have been found in the literature so far.

\section{Analytical framework}

Following both the relevant economic theory and the accumulated empirical knowledge, we make use of a growth equation based on the standard empirical growth literature (e.g., Barro and Sala-i-Martin, 2004), augmented by debt to assess whether the latter has an impact on growth over and above other determinants.

\footnotetext{
${ }^{15}$ See Gómez-Puig and Sosvilla-Rivero (2017) for a detailed review of this literature.

${ }^{16}$ Current account surpluses in core countries, deficits in the periphery, real exchange rate divergence, heterogeneities in the banking sector, differences in the degree of competitiveness or different rates of productivity growth, to name a few.
} 
The initial empirical specification is derived from the neoclassical growth model:

$$
g_{t}=\alpha+\gamma y_{t-1}+\sum_{i=1}^{n} \delta_{i} X_{i t}+\beta d_{t}+\varepsilon_{t}
$$

where $g_{t}$ is the growth rate of real per capita GDP, $y_{t-1}$ is the logarithm of initial real per capita GDP, $X_{i t}(i=1, \ldots, \mathrm{n})$ is a set of explanatory regressors and $d_{t}$ is the debt-to-GDP ratio. Following Cecchetti et al. (2011), household $\left(b d_{t}\right)$, corporate $\left(c d_{t}\right)$ and public $\left(p d_{t}\right)$ debt are treated separately.

The initial level of initial real per capita GDP is introduced in equation (1) to capture the conditional convergence of the economy to its steady state. Regarding $X_{t}$, we consider a set of explanatory variables that have been shown to be consistently associated with growth in the literature: population growth rate $\left(P O P G R_{t}\right)$; the ratio of gross savings to GDP $\left(G S_{t}\right)$; the level of human capital $\left(H K_{t}\right)$; openness to trade $\left(O P E N_{t}\right)$; and CPI inflation $\left(I N F_{t}\right)^{17}$.

POPGR $_{t}$ is used to proxy country size and the rate of labour growth to reflect its importance as key determinant of growth (Solow, 1956 or Frankel, 1962). Regarding $G S_{t,}$ it is posited that increased savings may stimulate economic growth through increased investment (Keynes, 1936; Harrod, 1939; Domar, 1946; and Solow, 1956). As for $H K_{\text {t, }}$ since various theoretical models include human capital as a factor of production and emphasise the accumulation of human capital as a crucial element of the growth process, we use life expectancy at birth as a proxy for human capital ${ }^{18}$. In relation to OPEN (measured by the absolute sum of exports and imports over GDP), the theoretical literature suggest that it increases productivity through transfers of knowledge and efficiency gains (Seghezza and Baldwin, 2008). Finally, although the relationship between inflation and growth remains controversial in both theory and empirical findings ${ }^{19}$, most of the studies highlight that inflation leads to uncertainty and thus predict a negative relationship [see De Gregorio (1993) or Friedman (1977), among others].

\footnotetext{
${ }^{17} \mathrm{We}$ also considered other potential explanatory regressors widely used in the empirical literature such as the interest rate, the real effective exchange rate, the government deficit-to-GDP ratio, an index of fiscal stance and the total dependency ratio as a measure of population structure and ageing, but they turned out to be not significant in our final estimated equations resulting from the general-to-specific econometric modelling approach performed in section 7.

${ }_{18}$ This proxy is also used by Sachs and Warner (1997). As shown in Jayachandran and Lleras-Muney (2009), longer life expectancy encourages human capital accumulation, since a longer time horizon increases the value of investments that pay out over time. Moreover, better health and education are complementary with longer life expectancy (Becker, 2007). Indeed, life expectancy at birth correlates strongly with the index of human capital per person provided by the Penn World Table (version 8.0, Feenstra et al., 2013), based on years of schooling (Barro and Lee, 2013) and returns to education (Psacharopoulos, 1994).

19 Tobin (1965) suggests that an increase in inflation raises capital formation in the long run because it reduces the real return to holding money and causes a portfolio shift towards capital, while Dotsey and Sarte (2000) show that inflation variability may increase investment through its impact on precautionary savings, enhancing economic growth.
} 


\section{Data and time series properties}

\subsection{Data}

As mentioned above, we use annual data for ten EMU countries: both central (Austria, Belgium, Finland, France, Germany and the Netherlands) and peripheral countries (Greece, Italy, Portugal and Spain). We use the largest sample we could have with the available data covering the period 1980-2015 (i.e., a total of 36 annual observations) to explore the dimension of historical specificity and to capture the underlying relationship between the variables under study ${ }^{20}$.

To maintain as much homogeneity as possible for a sample of ten countries over the course of more than three decades, we use the World Bank's World Development Indicators ${ }^{21}$ as our primary source, supplemented with data from Cecchetti et al. (2011), the European Commission's AMECO database and the International Monetary Fund (International Financial Statistics 2016b). As stated above, we use per capita GDP at 2010 market prices, population growth rate, the ratio of gross savings to GDP, an index of human capital, openness to trade and consumer price inflation. The precise definitions and sources of the variables are presented in Appendix 1.

\subsection{Time series properties}

In order to document the possible differences in their experiences, our approach focuses on time series analyses of yearly data for the individual countries in our sample to empirically assess their underlying debt-growth nexus.

Given that most macroeconomic data exhibit non-stationary, we tested for the order of integration of the variables under study by means of the Augmented Dickey-Fuller (ADF) tests. The results decisively reject the null hypothesis of a unit root at conventional significance levels for $g_{t}, I N F_{t}, P O P G R_{t}$ and $G S_{t}$ (indicating that they are stationary in levels), while we do not reject the null for $y_{t}, b d_{t}, c d_{t}, p d_{t}$, OPEN $N_{t}$ and $H K_{t}$ (suggesting that these variables can be treated as first-difference stationary) ${ }^{22}$. Then, following Carrion-i-

\footnotetext{
${ }^{20}$ As Hakkio and Rush (1991) and Campbell and Perron (1991) pointed out, the ability to detect long run relationships is a function of the total sample length and not a function of data frequency. Therefore, to ensure the quality of the analyses, we use 36 annual time series observations, being the sample size determined by data availability. To deal with the relatively small-sample size, we use the small-sample degree-of-freedom correction factor that renders smallsample $t$ and $F$ statistics instead of the large-sample normal and chi-squared statistics. The standard errors are computed using the degrees of freedom for the equation.

21 http://data.worldbank.org/data-catalog/world-development-indicators

${ }^{22}$ These results (which are not shown here in order to save space, but are available from the authors upon request) were confirmed using Phillips-Perron (1998) unit root tests controlling for serial correlation and heteroskedasticity in the
} 
Silvestre et al.'s (2001) suggestion, we confirm these results using the Kwiatkowski et al. (1992) (KPSS) tests, where the null is a stationary process against the alternative of a unit $\operatorname{root}^{23}$.

\section{Empirical models}

\subsection{Baseline empirical model}

A dependent stationary variable cannot be explained using non-stationary variables, since the statistical properties of the former (mean, variance, autocorrelation, etc.) remain constant over time while the statistical properties of the latter change over time. Therefore, we transform the non-stationary variables into stationary variables by differencing them and the baseline empirical model is modified as follows:

$$
g_{t}=\phi g_{t-1}+\delta_{1} I N F_{t}+\delta_{2} \Delta H K_{t}+\delta_{3} \Delta O P E N_{t}+\delta_{4} P O P G R_{t}+\delta_{5} G S_{t}+\beta \Delta d_{t}+\varepsilon_{t}
$$

where $\Delta$ denotes the first difference operator.

Note that model (2) is quite different from model (1), which is commonly used in the literature, especially regarding the variables $y_{t-1}, H K, O P E N$ and $d$, given there are found to be non-stationary. As explained in Asimakopoulos and Karavias (2016), equation (1) can be rewritten as

$$
g_{t}=\alpha+\gamma y_{t-1}+\sum_{i=1}^{l} \delta_{i}^{s} X_{i t}^{s}+\sum_{i=1}^{l} \delta_{i}^{n s} X_{i t}^{n s}+\beta d_{t}+\varepsilon_{t}
$$

where $X_{i t}^{s}$ and $X_{i t}^{n s}$ denote the stationary and non-stationary explanatory variables respectively. We can then compare the new equation (3) with equation (2). As can be seen, our baseline empirical model (2) has $g_{t-1}=\Delta y_{t-1}$ instead of $y_{t-1}, \Delta d_{t}$ instead of $d_{t}$ and $\Delta X_{i t}^{n s}$ instead of $X_{i t}^{n s}$ as explanatory variables due to non-stationarity. Therefore, the interpretation of the estimated parameters is the same in both models, but that of $\phi$, $\delta_{2}, \delta_{3}$ and $\beta$ changes.

errors, the Elliott, Rothenberg, and Stock (1996)'s modified ADF- generalized least squares unit root tests and the Ng and Perron (2001)'s modified efficient Phillips-Perron. These additional results are also available from the authors.

23 The results are not shown here due to space restrictions but are available from the authors upon request. 


\subsection{Asymmetric model}

We proceed further by exploring the possibility of a different effect on economic growth of positive and negative debt variation for each country, making use of the following alternative empirical specification ${ }^{24}$ :

$$
\begin{aligned}
& g_{t}=\phi g_{t-1}+\delta_{1} I N F_{t}+\delta_{2} \Delta H K_{t}+\delta_{3} \Delta O P E N_{t}+\delta_{4} P O P G R_{t}+\delta_{5} G S_{t} \\
& +\beta_{1} \Delta d_{t} I\left(\Delta d_{t}>0\right)+\beta_{2} \Delta d_{t} I\left(\Delta d_{t}<0\right)+\varepsilon_{t}
\end{aligned}
$$

where $I$ is an indicator function that takes the value 1 if the condition is fulfilled (i.e., if $\Delta$ is positive or negative) and zero otherwise. The indicator variable has the effect of splitting the variation of the debt variable into two, allowing for an asymmetric response of growth to debt accumulation and relief.

\subsection{Threshold model}

In order to account for the presence of country-specific tipping points ${ }^{25}$, we employ the following alternative specification:

$$
\begin{aligned}
& g_{t}=\phi g_{t-1}+\delta_{1} I N F_{t}+\delta_{2} \Delta H K_{t}+\delta_{3} \Delta O P E N_{t}+\delta_{4} P O P G R_{t}+\delta_{5} G S_{t} \\
& +\beta_{1} \Delta d_{t} I\left(d_{t} \leq d^{*}\right)+\beta_{2} \Delta d_{t} I\left(d_{t}>d^{*}\right)+\varepsilon_{t}
\end{aligned}
$$

where $I$ is an indicator function taking on the value 1 if the value of $d_{t}$ is either below or above a specific threshold value $d^{*}$, and zero otherwise. In this case, the indicator variable has the effect of splitting the variation of the debt variable into two, allowing for the impact to differ above and below the threshold. Note that in the assignment to one or the other regime we follow the usual practice in the literature and use the debt-to-GDP ratio as the primary variable of interest. To select the threshold, for each country we estimate

\footnotetext{
${ }^{24}$ For example, Eberhardt and Presbitero (2015) assess asymmetry in the long- and/or short-run relationship between public debt and growth in a large panel of countries in order to reflect the conclusions of the well-established literature on the asymmetric effects of fiscal policy in advanced economies (see, Sutherland, 1997; and Perotti, 1999). Nevertheless, their methodological approach is different from the one implemented in this paper, since we adopt a times series analysis instead of a panel data approach and we deal appropriately with the different order of integration of the relevant variables, using changes in debt-to-GDP ratio as the primary variable of interest.

25 Baum et al. (2013), Checherita-Westphal and Rother (2012), Dreger and Reimers (2013), Antonakakis (2014) and Gómez-Puig and Sosvilla-Rivero (2017) have found that, for EMU countries, the relationship between public debt and growth is characterized by the presence of a threshold above which debt starts to have a negative effect on economic growth. Caution should be taken when comparing results with those presented in Baum et al. (2013), Checherita-Westphal and Rother (2012), Dreger and Reimers (2013) or Antonakakis (2014) due to the fact that these papers adopt a panel data analysis and use the debt-to-GDP ratio as the primary variable of interest.
} 
equation (5) for all possible values for $d^{*}$ and then select the one that maximizes the adjusted $R^{2}$ as the relevant one ${ }^{26}$.

\section{Empirical results ${ }^{27}$}

In order to assess whether the proposed models are tentatively admissible (i.e., consistent with the data and with economic theory), we use a data-based method for obtaining a parsimony representation of the data-generating process: the general-to-specific approach (Hendry, 1995). In this approach, the modeller simplifies an initially general model that adequately characterizes the empirical evidence within his or her theoretical framework. Starting from a general unrestricted model that captures the essential characteristics of the underlying dataset, contains all relevant variables and sufficient lags, that general model is reduced in complexity by eliminating statistically insignificant variables, checking the validity of the reductions at every stage to ensure congruence of the finally selected model (see Faust and Whiteman, 1997) ${ }^{28}$. This method has proved useful in practice for selecting empirical economic models (see Hendry, 2000).

In order to address the potential problem of simultaneity or reverse causality between the growth rate and the explanatory variables, we use two-stage least squares (2SLS) instrumental variable techniques to estimate the finally selected model. In the case of the threshold model, we use the 2SLS estimator proposed by Caner and Hansen (2004). Following common practice with macroeconomic data, we use lagged terms of regressors as instruments.

Recall that, in order to assess the differences between types of borrowers, household, corporate and government debt $\left(b d_{t}, c d_{t}\right.$ and $p d_{t}$, respectively) are treated separately.

\subsection{Empirical results from the baseline empirical model}

Panel $\mathrm{A}$ in Tables $2 \mathrm{a}$ and $2 \mathrm{~b}$ reports the results for central and peripheral countries respectively. All explanatory variables turn out to be significant and their signs are in

\footnotetext{
${ }^{26}$ Note that, given the time series dimension adopted in this paper, the threshold $d^{*}$ detected for each country is dependent on the variability on the debt-to-GDP ratio in that country over the specific sample under study.

${ }^{27}$ In each model, we focus our comments on the variation in debt to investigate its effect on growth, summarizing the results by pointing out the main regularities. The reader is asked to browse through Tables 2 to 4 to find evidence for a particular country of her/his interest and for a detailed account of the impact of other explanatory variables on the growth rate. Note that, for expository convenience, in Tables 2 to 4 we show the results by distinguishing between central and peripheral EMU countries.

${ }^{28}$ Phillips (1988) contends that the general-to-specific methodology performs a set of corrections that make it an optimal procedure under weak exogeneity.
} 
concordance with the literature ${ }^{29}$. The degree of country's openness to trade, the proxy used to measure human capital, population growth and the ratio of gross savings to GDP have a positive impact on real GDP per capita growth, while the inflation rate and the ratio of debt over GDP exert a negative effect.

[Insert Table $2 \mathrm{a}$ and $2 \mathrm{~b}$ around here]

Some interesting insights emerge from the results presented in Tables 2 when analysing the effect of a debt increase in the three different sectors on per capita GDP growth. We observe that, on average in the ten countries under study, the highest marginal impact of a debt rise corresponds to the household and public sector (-0.2), the marginal effect of an increase in nonfinancial corporations' debt being much lower $(-0.1)$. However, there are important differences across countries. If there is an increase in households' debt, the estimated marginal effect on growth ranges from -0.54 in Greece to -0.03 in the Netherlands, and the response is higher in peripheral $(-0.27)$ than in central countries (0.17). A similar pattern is found when analysing the effect of an increase in nonfinancial firms' debt, since the marginal impact ranges from -0.34 in Greece to -0.003 in Germany and, on average, the influence is also higher in peripheral $(-0.19)$ than in central countries (0.09). However, even though the reaction to a public debt increase also differs across EMU countries (it ranges from -0.46 in Finland to -0.002 in Austria), the average value is very similar (close to -0.2) in central and peripheral countries.

Summing up, the results from the baseline model suggest that although the effects on nonfinancial debt accumulation clearly differ across countries, on average, the highest marginal impact of a debt rise corresponds to the household and public sector. Furthermore, an increase in private debt (both households and companies) is more harmful in peripheral than in central countries, while the average effect of a rise in public debt does not differ between these two groups of countries.

Finally, as can be seen in Panel B in Tables 2a and 2b, the estimated models seem to pass diagnostic tests such as normality of error term, second-order residual autocorrelation and heteroskedasticity $\left(\chi_{N}^{2}, \chi^{2}\right.$ and $\chi_{\mathrm{H}}^{2}$ respectively). The overall regression fit is satisfactory,

\footnotetext{
${ }^{29}$ Recall that the regression coefficients in Table 2 represent the mean change in the dependent variable (the growth rate of real per capita GDP) for one unit of change in a given explanatory variable while holding other explanatory variables in the model constant. Therefore, the estimated values for $\phi, \delta_{1}, \delta_{4}$ and $\delta_{5}$ isolate, respectively, the role of the lagged dependent variable, the inflation rate, the population growth and the gross savings-to-GDP ratio from all of the others explanatory variables in the model, while $\delta_{2}, \delta_{3}$ and $\beta$ identify the role of variations in human capital, openness and the debt-to-GDP ratio on real growth rate, respectively.
} 
as measured by the adjusted $R^{2}$ value (ranging from 0.5404 to 0.7575 for central EMU countries and from 0.5700 to 0.6979 for peripheral EMU countries). Therefore, our econometric modelling seems to have identified sensible and interpretable relationships between the economic variables under study.

\subsection{Empirical results from the asymmetric model}

As explained above, the introduction of an indicator variable in the asymmetric model has the effect of splitting the variation of the debt variable into two, allowing for a different response of growth to debt accumulation and relief.

[Insert Tables $3 \mathrm{a}$ and $3 \mathrm{~b}$ around here]

The results reported in Panel A in Tables 3 suggest that, on average, this asymmetric effect exists for households and governments. However, while in the households' sector the positive effect of a debt relief on growth (-0.3) is higher than the negative effect of a debt increase (-0.2), in the governments' sector the negative effect of a debt increase on growth $(-0.2)$ is higher than the positive impact of a debt reduction (-0.1). Conversely, for companies, the average marginal impact of a debt increase is the same as that of a debt reduction $(-0.1)$.

Regarding the effects of debt accumulation, the marginal effect of a debt increase also differs across countries regardless of the type of debt, and similar patterns to those resulting from the baseline model are found. The marginal response of an increase of household debt ranges from -0.51 in Greece to -0.04 in the Netherlands and, on average, the marginal influence is higher in peripheral $(-0.31)$ than in central countries $(-0.16)$. If companies' debt rises, the estimated marginal impact ranges from -0.39 in Greece to -0.04 in the Netherlands and, on average, it is higher in peripheral $(-0.19)$ than in central countries (-0.11). In the case of a positive change in public debt, the marginal reaction ranges from -0.46 in Finland to -0.02 in Austria but, as in the baseline model, the average response does not differ between central and peripheral economies $(-0.2$ in both groups of countries).

Therefore, the effects of debt accumulation on growth resulting from the asymmetric model also stress the fact that an increase in private debt has a higher detrimental effect on economic growth in peripheral than in central countries, while the effect is very similar in the two groups of countries if there is a rise in public debt. It is noticeable that in both the 
baseline and the asymmetric models an increase in private debt is especially harmful in Greece, while the effect of a public debt increase on Greek economic growth seems to be much lower.

Tables 3 present some very important evidence regarding the effects of debt reduction on growth. On average, for the ten countries under study, a debt reduction has estimated marginal impacts of $-0.3,-0.1$ and -0.1 in the case of the household, government, and firm sectors respectively, indicating that while a reduction in nonfinancial corporations' and public debt has a negligible effect on growth ${ }^{30}$, the response is relevant in the case of households.

Nevertheless, this significant positive reaction clearly differs across countries, the average impact being higher in peripheral than in central countries. Specifically, the marginal impact of debt deleveraging in the household sector presents values of $-0.74,-0.48,-0.41$ and -0.19 in Spain, Greece, Portugal and Italy respectively.

Consequently, in view of these results and considering that households' final consumption expenditure is the most important component of GDP in the countries under study (around 50\%), it is essential to point out that the huge increase in households' indebtedness (close to $160 \%$ over the last 36 years, mainly due to mortgage loans) has represented a significant impediment for economic growth, since it has crowded out consumption. Therefore, a reduction in households' debt (especially in EMU peripheral countries) may be crucial to stimulate consumption and growth; as the literature has stressed, households' debt plays a very important role in shaping the business cycle. Jordà et al. (2013) show that the presence of a high level of household debt leads to deeper recessions, while Mian et al. (2013) report the channel through which this might happen. Specifically, the latter authors highlight the role of household debt in explaining the large decline in U.S. consumption during the 2006-2009 period. In particular, since they find that the marginal propensity to consume is much higher for poorer households or those with higher leverage, their results suggest that the consequences of housing wealth decline on aggregate consumption will be more severe the higher the level of leverage in the housing sector.

30 Gómez-Puig and Sosvilla-Rivero (2017) also find the impact of public debt deleverage on EMU countries' economic growth to be insignificant. 
As stated above, the effects of households' debt relief in central EMU countries (Table 3a) are lower than in peripheral economies. In fact, a debt reduction only presents a positive relevant effect in Finland and Austria.

Finally, notice that we have conducted diagnostic tests in order to examine whether our results are free from problems of serial autocorrelation, heteroskedasticity and nonlinearity of residuals. As can be seen in Panel B of Tables 3, we found that none of these problems are present in our estimates. Additionally, the estimated adjusted $R^{2}$ statistics seem to suggest that a considerable fraction of the variance of the dependent variable is explained by the independent variables used in the regressions.

\subsection{Empirical results from the threshold model}

Panels $\mathrm{A}$ in Tables $4 \mathrm{a}$ and $4 \mathrm{~b}$ show $^{31}$ the results from the threshold model. As in the asymmetric model, an indicator variable has been introduced which splits the effect of the debt change into two, allowing in this case for the impact to differ below and above the threshold detected.

[Insert Tables $4 \mathrm{a}$ and $4 \mathrm{~b}$ around here]

Some interesting observations can also be drawn from Tables 4. First, it is noticeable that above the estimated threshold, on average, the estimated negative effect of an increase in public debt on growth $(-0.2)$ is similar to the one found using the baseline or the asymmetric model. However, the average negative reaction to an increase in private debt (both households and companies) is higher above the detected tipping point in the threshold model than in the two previous models. In the case of households, the average marginal impact increases from -0.2 to -0.3 , while in the case of nonfinancial corporations it rises from -0.1 up to -0.2 .

Second, on average, the highest thresholds are found for corporations' debt (87\%), followed by public debt (59\%) and households' debt (39\%). Our findings reflect the fact that firms' debt is, on average, twice as high as households' debt and around one third higher than that of the public sector during the 1980-2015 period (see Figure 2 and Table 1). According to our results, firms have greater room for manoeuvre to increase the level of 31 As can be seen in Panel $\mathrm{B}$ in Tables 4 , the regressions fit reasonably well in terms of adjusted $\mathrm{R}^{2}$ and they pass the
diagnostic tests against non-normal errors, autocorrelation and heteroskedasticity. 
indebtedness than the other sectors, and the public sector has a greater margin than households.

Third, focusing on the private sector, not only are debt thresholds lower for households' debt rather than for firms' debt, but also the average marginal effect $(-0.3)$ of a household debt increase on growth beyond the tipping point is higher than that of companies (-0.2). Moreover, in the two private sectors, thresholds are lower in peripheral than in central EMU countries (households' debt thresholds present average values of $31 \%$ and $44 \%$ in peripheral and central countries respectively, while the average values of firms' debt thresholds are $72 \%$ in peripheral and $96 \%$ in central countries) and the marginal impacts above them are very high in some of these peripheral economies (e.g., Greece presents a marginal impact of -0.76 and -0.55 beyond the $32 \%$ and $52 \%$ turning point for households' and firms' debt respectively). Therefore, these results suggest that an increase in households' debt (especially in peripheral countries) exerts a higher detrimental effect on growth than a rise in nonfinancial corporations' debt.

Fourth, analysing the results of the threshold model for the public sector, we find that while the tipping point is lower in central $(55 \%)$ than in peripheral $(65 \%)$ countries $^{32}$, the marginal impact beyond that point is similar in the two group of countries (around -0.2). Focusing on peripheral countries (Table $4 \mathrm{~b}$ ), thresholds are $90 \%, 71 \%, 50 \%$ and $50 \%$ in Italy, Greece, Portugal and Spain, while marginal impacts range from -0.3 in Spain and Italy to -0.2 in Portugal and -0.1 in Greece.

All in all, Tables 4 indicate that while public debt thresholds are higher in peripheral than in central countries, private debt thresholds are higher in core EMU countries. These results suggest that while peripheral countries might have a higher capacity to increase public indebtedness than central ones, in the case of private indebtedness central countries are in a better position to increase it. Consequently, public debt accumulation might exert a more harmful effect on central euro-area countries' economic growth, but the detrimental effect of an increase in private debt seems to be higher in peripheral countries. These results indicate that peripheral countries especially should be aware of the adverse consequences

\footnotetext{
32 Even though these results cannot be fully compared to those presented by Gómez-Puig and Sosvilla-Rivero (2017) since they analyse the public debt-growth nexus in EMU countries during a larger time period (1961-2015) and detect that, in most of the countries, thresholds take place before 1980 (when the sample period begins in this paper), it is noticeable that, on average they also find that public debt thresholds are lower in central $(40 \%)$ rather than in peripheral countries $(50 \%)$
} 
of private debt accumulation. Rather than disregarding private sector leveraging, they should pay it as much attention as they already do to public debt.

\section{Concluding remarks}

Total nonfinancial debt as a percentage of GDP, as well as its components, rose steadily for much of the 1980-2015 period. Starting at a relatively modest 147 percent of GDP in 1980, 36 years later total nonfinancial debt had reached 304 per cent of GDP in euro-area countries and, of this percentage, only one third corresponds to the public sector. In 2015 about two-thirds of total euro-area countries' nonfinancial debt has its origin in the private sector (both households and companies). However, while the unprecedented increase in public debt across EMU countries has raised serious concerns among economists about both its sustainability and its impact on economic growth, they have taken a more nuanced position regarding the risks of private debt accumulation, despite its magnitude. Nevertheless, all forms of nonfinancial debt should be sources of concern when they are high and register an upward trend.

This paper aimed to fill the existing gap in the literature by assessing the effect of all forms of nonfinancial debt (households, nonfinancial corporations and governments) on economic growth in euro-area countries. To do so, we used a methodology that explicitly takes into account the possible heterogeneity (see, e.g., Erberhart and Presbitero, 2015 or Chudick et al., 2017) in the relationship between each source of nonfinancial debt and growth across euro-area countries. In particular, our analytical strategy has rested on the estimation of an equation based on the empirical growth literature augmented by debt to assess its impact after controlling for the other determinants of growth. So, after ensuring that all the variables in the model have the same order of integration, and to provide a broad view of the debt-growth nexus, we successively estimated three models (a baseline, an asymmetric and a threshold model) for each of the ten countries in our sample and, following Cecchetti et al. (2011), we treated the different types of borrowers - households, corporations and governments - separately.

Summing up, the results from both the baseline and the asymmetric model suggest that although the effects on nonfinancial debt accumulation clearly differ across countries, on average the highest marginal impact of a debt rise corresponds to the household and public sector. Furthermore, an increase in private debt is more harmful in peripheral than in central EMU countries, while the average effect of a rise in public debt does not differ 
between these two groups of countries. Focusing on the effects of a debt increase beyond the turning point estimated in the threshold model, it is noticeable that above the estimated threshold, on average the negative effect of an increase in public debt on growth is similar to the one found using the baseline or the asymmetric model. However, the average negative reaction to an increase in private debt is higher above the detected tipping point in the threshold model than in the two previous ones. As a result, in the threshold model the highest marginal impact of a debt increase beyond the turning point corresponds to the household sector.

Our results also suggest that there exists an asymmetric effect for the household and government sectors. However, while in the households' sector the positive effect of a debt reduction on growth is higher than the negative effects of a debt increase, in the public sector the negative effect of a debt increase on growth is higher than the positive impact of a debt reduction. Furthermore, our findings indicate that while a reduction in nonfinancial corporations' or governments' debt has a negligible effect on growth, the response is relevant in the case of households. Nevertheless, the significant positive reaction of households' debt deleverage clearly differs across countries, the average impact being higher in peripheral countries (especially in Spain) than in their central counterparts.

Finally, it is noticeable that the highest thresholds are found for corporate debt $(87 \%)$, followed by public debt (59\%) and household debt (39\%). Focusing on the private sector, not only are debt thresholds lower for households rather than for firms, but also, beyond the detected tipping point, the average marginal effect of a household debt increase on growth is higher than that of companies' debt. Moreover, in the two private sectors, thresholds are lower in peripheral than in central EMU countries and the marginal impact above them is very high in some of these peripheral economies. Conversely, in the public sector we find lower thresholds in central than in peripheral countries.

Therefore, our findings seem to suggest that EMU central countries are more tolerant of a private debt increase than peripheral economies, and that the negative potential effect is higher in peripheral Member States than in core countries. Yet, although the warning signs of increased private leverage in the run-up to the crisis of 2008 were largely ignored (especially in peripheral countries), euro-area economies should now be aware of the adverse consequences of private debt accumulation and should be as concerned by private sector leveraging (in particular, in the household sector) as they are by public debt. 
Moreover, since we found a relevant response of households' debt on economic growth in EMU peripheral countries, its reduction might be crucial in those countries to stimulate consumption and growth.

Our results have significant policy implications. Empirical evidence on the impact of nonfinancial debt on economic growth helps to inform policy and stresses the importance of monitoring both private and public debt to stimulate economic growth. Additionally, the heterogeneous relationships detected in the debt-growth nexus suggest that the pace of deleveraging should be adapted to the differences in debt tolerance and impact in each EMU country; therefore, rigid and uniform criteria are not advisable when addressing the necessary adjustments.

Our contribution also provides guidance for theoretical models that seek to study the consequences of debt on economic growth. We show that private debt matters as well as public debt. Thus, the growing macroeconomic literature should focus more closely on private indebtedness when studying the capacity of an economy to produce goods and services over time in order to increase the validity and viability of these models and their ability to offer a systematic structural interpretation of economic reality.

A natural extension to the analysis presented in this article would be to explore the feedback loops between different types of debt and their impact on economic growth. This is an item in our future research agenda.

\section{Acknowledgements}

The authors wish to thank an anonymous referee and the editor for their helpful comments and suggestions on a previous draft of this article, which have enabled them to introduce substantial improvements. They also thank the members of the Department of Economics at the University of Bath and of the Department of Finance at Cass Business School (City, University of London) for their hospitality during their research visit.

\section{Funding}

This paper is based on work supported by the Instituto de Estudios Fiscales [grant IEF 015/2017], the Bank of Spain [grant PR71/15-20229], the Spanish Ministry of Education, Culture and Sport [grants PRX16/00261 and PRX17/00029] and the Spanish Ministry of Economy and Competitiveness [grant ECO2016-76203-C2-2-P]. 


\section{References}

Auray, S., Eyquem, A. 2017. Heterogeneity, Convergence and Imbalances in the Euro Area. Série de documents de Travail 2017-64. Centre de recherce en économie et statistique.

Aldici, C., Belke, A., Giovannini, A., Gros, D. (2016). Macroeconomic adjustment programmes in the euro area: An overall assessment. International Economics and Economic Policy 13, 345-358.

Alves, J. Pereira, R. 2017. The Portuguese households' indebtedness. Working Paper 07/2017. Research Unit on Complexity and Economics, University of Lisbon, Lisbon

Angeletos, G. M., Collard, F., Dellas, H., 2016. Public debt as private liquidity: Optimal policy, Technical report, National Bureau of Economic Research, Cambridge, MA.

Antonakakis, N. 2014. Sovereign debt and economic growth revisited: The role of (non-) sustainable debt thresholds. Working Paper 187, Department of Economics, University, Vienna, Vienna.

Asimakopoulos, S., Karavias, Y. 2016. The impact of government size on economic growth: A threshold analysis. Economics Letters 139, 65-68.

Barnes, S., Young, G. 2003. The rise in US household debt: assessing its causes and sustainability. Bank of England Working Paper No 206.

Barro, R., Lee, J.-W. 2013. A new data set of educational attainment in the world, 1950-2010. Journal of Development Economics 104, 184-198.

Barro, R. B., Sala-i-Martin, X. 2004. Economic growth, 2nd ed. The MIT Press, Cambridge MA.

Baum, A., Checherita-Westphal, C. and Rother, P. 2013. Debt and growth: New evidence for the Euro Area. Journal of International Money and Finance 32, 809-821.

Becker, G. S. 2007. Health as human capital: Synthesis and extensions. Oxford Economic Papers 59, 379-410.

Bernardini, M., Peersman, G., 2015. Private debt overhang and the government spending multiplier: evidence for the United States. Working Paper 2015/901, Ghent University, Ghent.

Campbell, J. Y., Perron, P., 1991. Pitfalls and opportunities: What macroeconomists should know about unit roots. NBER Macroeconomics Annual 6, 141-201.

Caner, M., Hansen, B., 2004. Instrumental variable estimation of a threshold model. Econometric Theory 20, 813-843.

Carrión-i-Silvestre, J.L., Sansó-i-Roselló, A., Ortuño, M.A. 2001. Unit root and stationarity tests wedding. Economics Letters 70, 1-8.

Cecchetti, S. G., Mohanty, M., Zampolli, F. 2011. The real effects of debt. In: Economic Symposium Conference Proceedings. Federal Reserve Bank of Kansas City, 145-196.

Checherita-Westphal, C., Rother, P. 2012. The impact of high government debt on economic growth and its channels: An empirical investigation for the Euro Area. European Economic Review 56, 1392-1405.

Chudik, A., Mohaddes, K., Pesaran, M.H., Raissi, M. 2017. Is there a debt-threshold effect on output growth? Review of Economics and Statistics 99, 135-150.

Crowe, C.W., Dell'Ariccia, G., Igan, D., Rabanal, P. 2011. How to deal with real estate booms: lessons from country experiences. International Monetary Fund Working Paper No. 11/91. Washington D.C.

Cuerpo, C., Drumond, I., Lendvai, J., Pontuch, P. Raciborski, R. 2015. Private sector deleveraging in Europe. Economic Modelling 44, 372-383. 
De Gregorio, J., 1993. Inflation, taxation, and long-run growth. Journal of Monetary Economics 31, 271-298.

Demirci, I., Huang, J., Sialm, C. 2017. Government debt and corporate leverage: International evidence, Working Paper 23310. National Bureau of Economic Research, Cambridge, MA.

Domar, E. D., 1946. Capital expansion, rate of growth, and employment. Econometrica 14, 137-147.

Dotsey, M., Sarte, P.D. 2000. Inflation uncertainty and growth in a cash-in-advance economy. Journal of Monetary Economics 45, 631-655.

Dreger, C., Reimers, H.E. 2013. Does euro area membership affect the relation between GDP growth and public debt? Journal of Macroeconomics 38, 481-486.

Eberhardt, M., Presbitero, A. F. 2015. Public debt and growth: Heterogeneity and non-linearity. Journal of International Economics 97, 45-58.

Elliott, G., Rothenberg, T.J., Stock, J.H. 1996. Efficient tests for an autoregressive unit root, Econometrica 64, 813-836.

Faust. J., Whiteman, C.H. 1997. General-to-specific procedures for fitting a data-admissible, theory-inspired, congruent, parsimonious, encompassing, weakly exogenous, identified, structural model to the DGP: A translation and critique, International Finance Discussion Papers 1997-576, Board of Governors of the Federal Reserve System, Washington D. C.

Feenstra, R.C., Inklaar, R., Timmer, M.P. 2013. The next generation of the Penn World Table, available for download at www.ggdc.net/pwt

Frankel, M. 1962. The production function in allocation and growth: A synthesis. American Economic Review 52, 996-1022.

Friedman, M. 1977. Nobel lecture: Inflation and unemployment. Journal of Political Economy $85,451-472$.

Garriga, C., Noeth, B., Schlagenhauf, D. E. 2017. Household debt and the Great Recession. Federal Reserve Bank of St. Louis Review 99, 183-205.

Ghosh, A. R., Kim, J.I., Mendoza, E. G., Ostry, J.D., Qureshi, M.S. 2013. Fiscal fatigue, fiscal space and debt sustainability in advanced economies. The Economic Journal 123, F4-F30.

Gómez-Puig, M., Sosvilla-Rivero, S. 2013. Granger-causality in peripheral EMU public debt markets: A dynamic approach. Journal of Banking and Finance 37, 4627-4649.

Gómez-Puig, M., Sosvilla-Rivero, S. 2017. Heterogeneity in the debt-growth nexus: Evidence from EMU countries. International Review of Economics and Finance 51, 470-486.

Gómez-Puig, M., Sosvilla-Rivero, S., Ramos-Herrera, M.C. 2014. An update on EMU sovereign yield spread drivers in times of crises: A panel data analysis. The North American Journal of Economics and Finance 30, 133-153.

Guerini, M., Moneta, A., Napoletano, M. Roventini, A. 2017. The Janus-faced nature of debt: Results from a data-driven Cointegrated SVAR approach. Working Paper 2017-02, Observatoire Français des Conjonctures Économiques, Paris

Hakkio, C. S., Rush, M. 1991. Cointegration: How short is the long run? Journal of International Money and Finance 10, 571-581

Harrod, R., 1939. An essay in dynamic theory. Economic Journal 49, 14-33

Hendry, D.F. 1995. Dynamic Econometrics. Oxford University Press, Oxford.

Hendry, D.F. 2000. Epilogue: The success of general-to-specific model selection. In Econometrics: Alchemy or Science? Oxford: Oxford University Press (pp. 467-490).

International Monetary Fund, 2016a. Debt-Use it wisely. Fiscal Monitor, October, Washington DC. 
International Monetary Fund, 2016b. World Economic Outlook, October, Washington DC.

Jarmuzek, M., Roz, R. 2017. Excessive Private Sector Leverage and Its Drivers: Evidence from Advanced Economies. International Monetary Fund Working Paper 17/72.

Jayachandran, S., Lleras-Muney, A. 2009. Life expectancy and human capital investments: Evidence from maternal mortality declines. Quarterly Journal of Economics 124, 349-397.

Jordà, O. Schularick, M., Taylor, A.M. 2013. When Credit Bites Back. Journal of Money, Credit and Banking 45, 3-28.

Jordà, O. Schularick, M., Taylor, A.M. 2016a. Sovereigns versus banks: credit, crises and consequences. Journal of the European Economic Association 14, 45-79

Jordà, O. Schularick, M., Taylor, A.M. 2016b. The great mortgaging: Housing finance, crises, and business cycles. Economic Policy 131, 107-152.

Kalemi-Ozcan, S., Papaioannou, E., Peydró-Alcalde, J.L., 2010. What lies beneath the Euro's effect on financial integration? Currency risk, legal harmonization, or trade? Journal of International Economics 81, 75-88.

Keynes, J. M. 1936. The General Theory of Employment, Interest and Money. London: Macmillan.

Klein, M. 2016. Austerity and private debt, Beiträge zur Jahrestagung des Vereins für Socialpolitik 2016: Demographischer Wandel - Session: Panel Macroeconometrics, No. C01-V2

Klein, M., Winkler, R., 2017. Austerity, inequality and private debt overhang, Discussion Paper 1633, German Institute for Economic Research, Berlin,

Kuvshinov, D., Müller, G., Wolf, M. 2016. Deleveraging, deflation and depreciation in the euro area. European Economic Review 88, 42-66.

Kwiatkowski, D., Phillips, P. C. B, Schmidt, P., Shin, Y. 1992. Testing the null hypothesis of stationary against the alternative of a unit root. Journal of Econometrics 54, 159-178.

Li, W., White, M. J. 2009. Mortgage default, foreclosure, and bankruptcy. Working Paper 15472. National Bureau of Economic Research, Cambridge, MA.

Lombardi, M., Mohanty, M., Shim, I. 2017. The real effects of household debt in the short and long run. Working Papers No 607, Bank for International Settlements, Basel.

Lydon, R., McIndoe-Calder, T. 2017. The great Irish (de) leveraging 2005-14. Research Technical Paper. 05/2017. Central Bank of Ireland.

Markus, A., Rainer, S. 2016. Public debt and economic growth: Economic systems matter, Discussion Paper 281, Center for European Governance and Economic Development Research, Göttingen.

Mian, A., Rao, K., Sufi, 2013. Household Balance Sheets, Consumption, and the Economic Slump. The Quarterly Journal of Economics 128 (4), 1687-1726.

Mian, A., Sufi, A., Verner, E. 2017. Household debt and business cycles worldwide. The Quarterly Journal of Economics, forthcoming.

Newey, W.K., West, K.D. 1987. A simple, positive semi-definite, heteroskedasticity and autocorrelation consistent covariance matrix. Econometrica 55, 703-708.

Ng, S., Perron, P., 2001. Lag length selection and the construction of unit root tests with good size and power. Econometrica 69, 1519-1554.

Perotti, R. 1999. Fiscal policy in good times and bad. Quarterly Journal of Economics 114, 1399-1436.

Pescatori, A., Sandri, D., Simon, J. 2014. Debt and growth: Is there a magic threshold? Working Paper 14/34, International Monetary Fund, Washington D. C. 
Phillips, P.C.B. 1988. Reflections on econometric methodology. Economic Record 64, 344 359.

Phillips, P.C.B., Perron, P. 1988. Testing for a unit root in time series regression. Biometrika 75, 335-346.

Psacharopoulos, G. 1994. Returns to investment in education: a global update, World Development 22, 1325-1343.

Randveer, M., Uusküla, L., Kulu, L., 2011. The impact of private debt on economic growth. Working Paper 10/2011. Bank of Estonia, Tallin

Romer, P. M. 1992. Two strategies for economic development: Using ideas and producing ideas. World Bank Economic Review 6 (Sup 1), 63-91.

Ruscher, E.,Wolff, G. 2013. Corporate balance sheet adjustment: stylised facts, causes and consequences. Review of Economics 64, 117-137

Sachs, J.D., Warner, A.W. 1997. Fundamental sources of long-run growth. American Economic Review, 87, 184-188.

Schmitz, B., von Hagen, J. 2011. Current Account Imbalances and Financial Integration in the Euro Area. Journal of International Money and Finance Vol. 30 (8), 1676-1695.

Schularick, M. 2013. Public and private debt: The historical record (1870-2010). German Economic Review 15, 191-207

Schularick, M., Taylor, A.M. 2012. Credit booms gone bust: Monetary policy, leverage cycles, and financial crises, 1870-2008. American Economic Review 102, 1029-1061.

Seghezza, E. and Baldwin, R. E. 2008. Testing for trade-induced investment-led growth. Economia Internazionale/International Economics 61, 507-537.

Singh, M.K., Gómez-Puig, M., Sosvilla-Rivero, S. 2016. Sovereign-bank linkages: Quantifying directional intensity of risk transfers in EMU countries. Journal of International Money and Finance 63, 137-164.

Solow, R. M. 1956. A contribution to the theory of economic growth. Quarterly Journal of Economics 70, 65-94.

Spiegel, M., 2009. Monetary and financial integration in the EMU: push or pull? Review of International Economics 17, 751-776.

Sutherland, A., 1997. Fiscal crises and aggregate demand: can high public debt reverse the effects of fiscal policy? Journal of Public Economics 65, 147-162.

Sutherland, D., Hoeller, P. 2012. Debt and Macroeconomic stability: An overview of the literature and some empirics. Working Paper 1006, Economics Department, Organisation for Economic Co-operation and Development, Paris.

Teles, V., Mussolini, C. (2014). Public debt and the limits of fiscal policy to increase economic growth. European Economic Review 66, 1-15.

Tobin, J. 1965. Money and economic growth. Econometrica 33, 671-810

Unger, R. 2017. Asymmetric Credit Growth and Current Account Imbalances in the Euro Area. Journal of International Money and Finance Vol. 73, 435-451.

Uusküla, L., 2016. Explaining private debt. Review of Economic Analysis 8, 153-176. 
Appendix 1: Definition of the explanatory variables and data sources

\begin{tabular}{|c|c|c|}
\hline Variable & Description & Source \\
\hline Real growth rate $\left(g_{t}\right)$ & Growth rate of real per capita GDP (annual \%) & World Development Indicators (World Bank) \\
\hline Level of Output $\left(y_{t}\right)$ & Per capita Gross domestic product at 2010 market prices & $\begin{array}{c}\text { AMECO, extended to } 2015 \text { using International } \\
\text { Monetary Fund (2016b) }\end{array}$ \\
\hline Household debt-to-GDP ratio $\left(b d_{t}\right)$ & $\begin{array}{l}\text { Household and non-profit institutions serving households debt } \\
\text { (all liabilities) as percentage of GDP }\end{array}$ & $\begin{array}{c}\text { Cecchetti et al. (2011) extended to } 2015 \text { using AMECO } \\
\text { http://www.bis.org/publ/work352 data.xls }\end{array}$ \\
\hline $\begin{array}{l}\text { Nonfinancial corporate debt-to- } \\
\text { GDP ratio }\left(c d_{t}\right)\end{array}$ & $\begin{array}{c}\text { Nonfinancial corporate debt (all liabilities less shares and other } \\
\text { equity) as percentage of GDP }\end{array}$ & $\begin{array}{c}\text { Cecchetti et al. (2011) extended to } 2015 \text { using AMECO } \\
\text { http://www.bis.org/publ/work352 data.xls }\end{array}$ \\
\hline Public debt-to-GDP ratio $\left(p d_{t}\right)$ & Ratio of public debt to GDP & AMECO and International Monetary Fund (2016b) \\
\hline Population growth $\left(P O P G R_{t}\right)$ & Population growth (annual \%) & World Development Indicators (World Bank) \\
\hline GS-to-GDP ratio $\left(G S_{t}\right)$ & Ratio of gross savings to GDP $(\%)$ & World Development Indicators (World Bank) \\
\hline Human capital $\left(H K_{t}\right)$ & Life expectancy at birth, total (years) & World Development Indicators (World Bank) \\
\hline Openess $\left(O P E N_{t}\right)$ & Absolute sum of exports and imports over GDP & World Development Indicators (World Bank) \\
\hline Inflation $\left(I N F_{t}\right)$ & $\begin{array}{l}\text { Inflation as measured by the consumer price index } \\
\text { (annual \%) }\end{array}$ & World Development Indicators (World Bank), \\
\hline
\end{tabular}


Figure 1. Nonfinancial debt-to-GDP by sector in EMU countries: 1980-2015

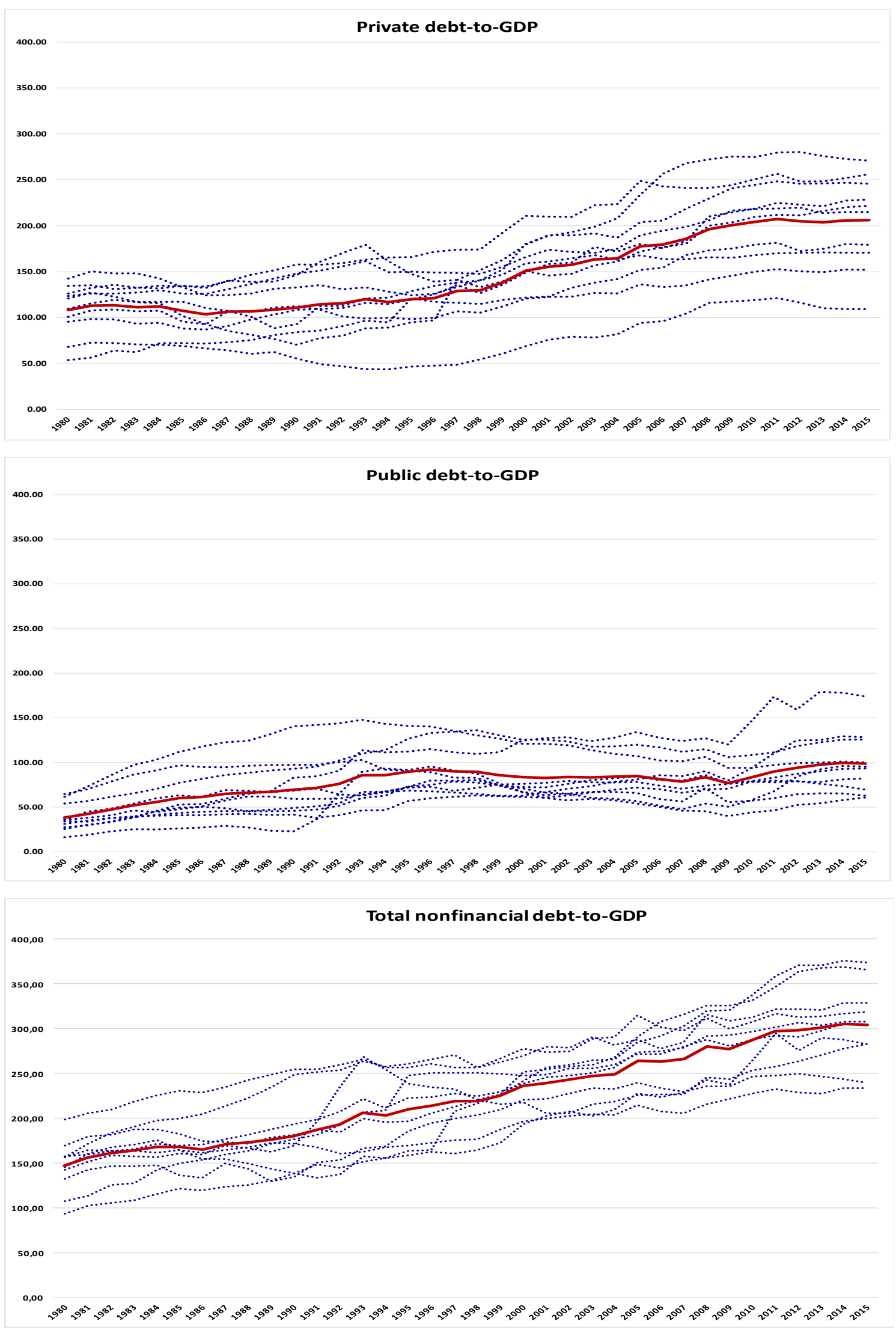

Source: Cecchetti et al. (2011) extended to 2015 using AMECO (http://www.bis.org/publ/work352 data.xls) and International Monetary Fund. Red lines correspond to the average values. 
Figure 2. Private debt-to-GDP by sector in EMU countries: 1980-2015
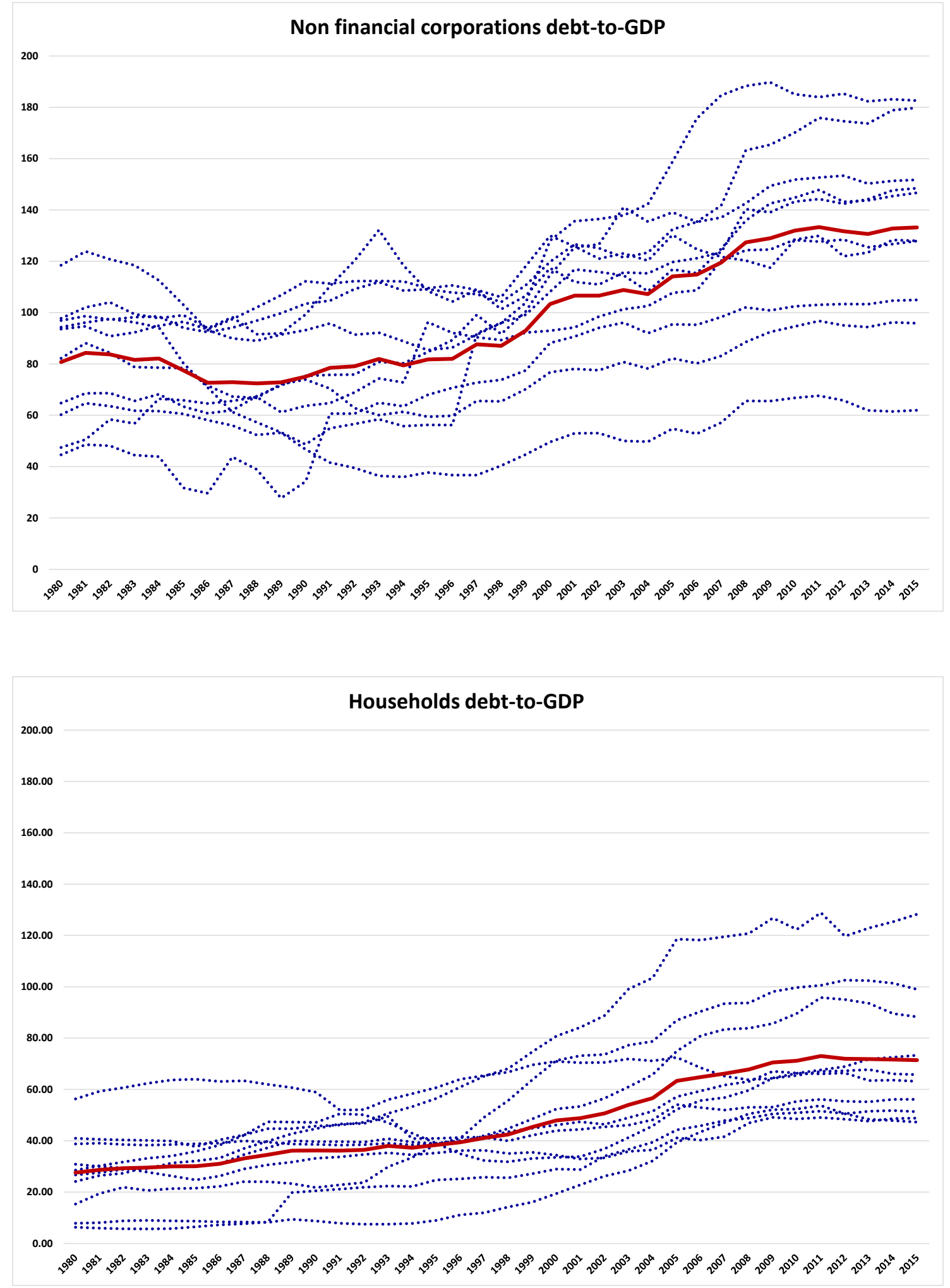

Source: Cecchetti et al. (2011) extended to 2015 using AMECO (http://www.bis.org/publ/work352 data.xls) Red lines correspond to the average values. 
Table 1a. EMU central countries sectoral debt as a percentage of GDP

\begin{tabular}{|c|c|c|c|c|c|c|c|c|c|c|c|}
\hline \multirow[b]{2}{*}{ AUSTRIA } & \multicolumn{6}{|c|}{ Levels } & \multicolumn{5}{|c|}{ Changes } \\
\hline & 1980 & 1990 & 1999 & 2009 & 2012 & 2015 & $1980-1990$ & 1990-1999 & 1999-2009 & 2009-2012 & 2012-2015 \\
\hline Households & 38.8 & 38.6 & 42.1 & 53.1 & 55.4 & 56.2 & $-0.4 \%$ & $9.1 \%$ & $26.0 \%$ & $4.3 \%$ & $1.4 \%$ \\
\hline Nonfinancial corporations & 82.2 & 73.9 & 70.2 & 92.4 & 95.0 & 95.9 & $-10.1 \%$ & $-5.0 \%$ & $31.7 \%$ & $2.8 \%$ & $0.9 \%$ \\
\hline General Government & 35.7 & 59.1 & 75.4 & 75.8 & 78.8 & 82.1 & $65.6 \%$ & $27.5 \%$ & $0.6 \%$ & $3.9 \%$ & $4.2 \%$ \\
\hline BELGIUM & 1980 & 1990 & 1999 & 2009 & 2012 & 2015 & 1980-1990 & 1990-1999 & 1999-2009 & 2009-2012 & 2012-2015 \\
\hline Households & 30.9 & 33.2 & 35.5 & 49.1 & 48.4 & 48.8 & $7.5 \%$ & $6.9 \%$ & $38.5 \%$ & $-1.4 \%$ & $0.8 \%$ \\
\hline Nonfinancial corporations & 64.8 & 75.3 & 100.4 & 165.4 & 174.6 & 179.8 & $16.3 \%$ & $33.3 \%$ & $64.7 \%$ & $5.6 \%$ & $3.0 \%$ \\
\hline General Government & 61.5 & 140.5 & 126.8 & 93.9 & 99.3 & 100.0 & $128.5 \%$ & $-9.7 \%$ & $-25.9 \%$ & $5.8 \%$ & $0.7 \%$ \\
\hline FINLAND & 1980 & 1990 & 1999 & 2009 & 2012 & 2015 & 1980-1990 & 1990-1999 & 1999-2009 & 2009-2012 & 2012-2015 \\
\hline Households & 28.5 & 47.2 & 33.1 & 64.5 & 68.9 & 73.3 & $65.2 \%$ & $-29.8 \%$ & $94.8 \%$ & $6.9 \%$ & $6.4 \%$ \\
\hline Nonfinancial corporations & 97.8 & 99.3 & 106.5 & 139.1 & 142.4 & 148.5 & $1.6 \%$ & $7.2 \%$ & $30.6 \%$ & $2.4 \%$ & $4.3 \%$ \\
\hline General Government & 16.3 & 22.8 & 76.5 & 40.0 & 52.3 & 60.8 & $40.5 \%$ & $234.9 \%$ & $-47.7 \%$ & $30.9 \%$ & $16.3 \%$ \\
\hline FRANCE & 1980 & 1990 & 1999 & 2009 & 2012 & 2015 & 1980-1990 & 1990-1999 & 1999-2009 & 2009-2012 & 2012-2015 \\
\hline Households & 26.7 & 44.7 & 44.9 & 67.1 & 66.4 & 63.1 & $67.5 \%$ & $0.5 \%$ & $49.4 \%$ & $-1.0 \%$ & $-5.0 \%$ \\
\hline Nonfinancial corporations & 96.9 & 103.4 & 110.7 & 149.4 & 153.3 & 151.7 & $6.7 \%$ & $7.0 \%$ & $35.0 \%$ & $2.7 \%$ & $-1.0 \%$ \\
\hline General Government & 34.1 & 45.8 & 74.3 & 76.6 & 87.3 & 93.2 & $34.6 \%$ & $62.2 \%$ & $3.0 \%$ & $14.0 \%$ & $6.8 \%$ \\
\hline GERMANY & 1980 & 1990 & 1999 & 2009 & 2012 & 2015 & $1980-1990$ & 1990-1999 & 1999-2009 & 2009-2012 & 2012-2015 \\
\hline Households & 56.3 & 59.0 & 69.6 & 64.3 & 67.3 & 65.8 & $4.73 \%$ & $18.05 \%$ & $-7.54 \%$ & $4.55 \%$ & $-2.25 \%$ \\
\hline Nonfinancial corporations & 44.6 & 34.2 & 77.5 & 100.8 & 103.3 & 104.9 & $-23.32 \%$ & $126.58 \%$ & $30.16 \%$ & $2.49 \%$ & $1.54 \%$ \\
\hline General Government & 31.2 & 41.6 & 62.3 & 70.6 & 79.2 & 69.5 & $33.38 \%$ & $49.50 \%$ & $13.34 \%$ & $12.21 \%$ & $-12.17 \%$ \\
\hline NETHERLANDS & 1980 & 1990 & 1999 & 2009 & 2012 & 2015 & 1980-1990 & 1990-1999 & 1999-2009 & 2009-2012 & 2012-2015 \\
\hline Households & 41.0 & 45.7 & 74.7 & 126.8 & 119.7 & 128.2 & $11.6 \%$ & $63.3 \%$ & $69.7 \%$ & $-5.6 \%$ & $7.1 \%$ \\
\hline Nonfinancial corporations & 93.6 & 112.2 & 118.1 & 117.5 & 128.5 & 127.9 & $19.8 \%$ & $5.3 \%$ & $-0.5 \%$ & $9.3 \%$ & $-0.5 \%$ \\
\hline General Government & 64.6 & 97.3 & 74.2 & 55.4 & 64.3 & 62.8 & $50.7 \%$ & $-23.7 \%$ & $-25.4 \%$ & $16.1 \%$ & $-2.4 \%$ \\
\hline
\end{tabular}

Table 1b. EMU peripheral countries sectoral debt as a percentage of GDP

\begin{tabular}{|l|c|c|c|c|c|c|c|c|c|c|c|}
\cline { 2 - 11 } \multicolumn{1}{c|}{} & \multicolumn{9}{|c|}{ Levels } & \multicolumn{7}{c|}{ Changes } \\
\hline GREECE & $\mathbf{1 9 8 0}$ & $\mathbf{1 9 9 0}$ & $\mathbf{1 9 9 9}$ & $\mathbf{2 0 0 9}$ & $\mathbf{2 0 1 2}$ & $\mathbf{2 0 1 5}$ & $\mathbf{1 9 8 0 - 1 9 9 0}$ & $\mathbf{1 9 9 0 - 1 9 9 9}$ & $\mathbf{1 9 9 9 - 2 0 0 9}$ & $\mathbf{2 0 0 9 - 2 0 1 2}$ & $\mathbf{2 0 1 2 - 2 0 1 5}$ \\
\hline Households & 7.8 & 8.7 & 16.1 & 52.1 & 50.5 & 47.3 & $11.6 \%$ & $84.9 \%$ & $222.6 \%$ & $-2.9 \%$ & $-6.5 \%$ \\
Nonfinancial corporations & 60.2 & 46.7 & 44.7 & 65.5 & 65.8 & 62.0 & $-22.5 \%$ & $-4.2 \%$ & $46.5 \%$ & $0.4 \%$ & $-5.8 \%$ \\
General Government & 25.5 & 82.9 & 111.6 & 120.1 & 159.2 & 173.8 & $224.7 \%$ & $34.7 \%$ & $7.6 \%$ & $32.6 \%$ & $9.2 \%$ \\
\hline ITALY & $\mathbf{1 9 8 0}$ & $\mathbf{1 9 9 0}$ & $\mathbf{1 9 9 9}$ & $\mathbf{2 0 0 9}$ & $\mathbf{2 0 1 2}$ & $\mathbf{2 0 1 5}$ & $\mathbf{1 9 8 0 - 1 9 9 0}$ & $\mathbf{1 9 9 0 - 1 9 9 9}$ & $\mathbf{1 9 9 9 - 2 0 0 9}$ & $\mathbf{2 0 0 9 - 2 0 1 2}$ & $\mathbf{2 0 1 2 - 2 0 1 5}$ \\
\hline Households & 6.3 & 20.5 & 27.2 & 50.5 & 50.5 & 51.3 & $224.8 \%$ & $32.3 \%$ & $86.0 \%$ & $0.0 \%$ & $1.6 \%$ \\
Nonfinancial corporations & 47.4 & 63.7 & 92.2 & 124.6 & 121.9 & 128.0 & $34.2 \%$ & $44.8 \%$ & $35.1 \%$ & $-2.1 \%$ & $5.0 \%$ \\
General Government & 54.0 & 92.8 & 130.4 & 105.9 & 118.2 & 125.7 & $72.0 \%$ & $40.4 \%$ & $-18.8 \%$ & $11.6 \%$ & $6.3 \%$ \\
\hline PORTUGAL & $\mathbf{1 9 8 0}$ & $\mathbf{1 9 9 0}$ & $\mathbf{1 9 9 9}$ & $\mathbf{2 0 0 9}$ & $\mathbf{2 0 1 2}$ & $\mathbf{2 0 1 5}$ & $\mathbf{1 9 8 0 - 1 9 9 0}$ & $\mathbf{1 9 9 0 - 1 9 9 9}$ & $\mathbf{1 9 9 9 - 2 0 0 9}$ & $\mathbf{2 0 0 9 - 2 0 1 2}$ & $\mathbf{2 0 1 2 - 2 0 1 5}$ \\
\hline Households & 15.4 & 21.8 & 63.8 & 98.1 & 102.6 & 99.0 & $41.7 \%$ & $193.1 \%$ & $53.8 \%$ & $4.5 \%$ & $-3.4 \%$ \\
Nonfinancial corporations & 94.3 & 48.7 & 99.2 & 142.5 & 143.2 & 146.7 & $-48.4 \%$ & $103.7 \%$ & $43.7 \%$ & $0.4 \%$ & $2.5 \%$ \\
General Government & 35.8 & 68.4 & 62.7 & 80.0 & 124.7 & 128.2 & $91.3 \%$ & $-8.3 \%$ & $27.5 \%$ & $55.9 \%$ & $2.8 \%$ \\
\hline SPAIN & $\mathbf{1 9 8 0}$ & $\mathbf{1 9 9 0}$ & $\mathbf{1 9 9 9}$ & $\mathbf{2 0 0 9}$ & $\mathbf{2 0 1 2}$ & $\mathbf{2 0 1 5}$ & $\mathbf{1 9 8 0 - 1 9 9 0}$ & $\mathbf{1 9 9 0 - 1 9 9 9}$ & $\mathbf{1 9 9 9 - 2 0 0 9}$ & $\mathbf{2 0 0 9 - 2 0 1 2}$ & $\mathbf{2 0 1 2 - 2 0 1 5}$ \\
\hline Households & 24.1 & 39.7 & 48.5 & 85.7 & 95.0 & 88.3 & $64.5 \%$ & $22.2 \%$ & $76.7 \%$ & $10.9 \%$ & $-7.1 \%$ \\
Nonfinancial corporations & 118.5 & 93.2 & 103.8 & 189.7 & 185.2 & 182.6 & $-21.4 \%$ & $11.5 \%$ & $82.7 \%$ & $-2.4 \%$ & $-1.4 \%$ \\
General Government & 27.5 & 49.0 & 74.3 & 50.6 & 83.9 & 95.3 & $78.1 \%$ & $51.8 \%$ & $-31.9 \%$ & $65.9 \%$ & $13.6 \%$ \\
\hline
\end{tabular}

Source: Cecchetti et al. (2011) extended to 2015 using AMECO (http://www.bis.org/publ/work352 data.xls) and International Monetary Fund. 
Table 2a. Baseline empirical model. Central countries

\begin{tabular}{|c|c|c|c|c|c|c|c|c|c|c|c|c|c|c|c|c|c|c|}
\hline \multicolumn{19}{|c|}{ Panel A: Estimation results } \\
\hline & \multicolumn{3}{|c|}{ AT } & \multicolumn{3}{|c|}{ BE } & \multicolumn{3}{|c|}{ FI } & \multicolumn{3}{|c|}{$\overline{\text { FR }}$} & \multicolumn{3}{|c|}{$\overline{\text { GE }}$} & \multicolumn{3}{|c|}{$\mathbf{N L}$} \\
\hline & hd & $c d$ & $p d$ & hd & $c d$ & $p d$ & hd & $c d$ & $p d$ & hd & $c d$ & $p d$ & hd & $c d$ & $p d$ & hd & $c d$ & $p d$ \\
\hline $\begin{array}{c}g_{t-1} \\
I N F_{t} \\
\Delta H K_{t} \\
\Delta O P E N_{t} \\
\text { POPGRO }_{t} \\
G S_{t} \\
\Delta d_{t}\end{array}$ & \begin{tabular}{|c|}
0.3738 \\
$(2.7455)$ \\
-0.1081 \\
$(-3.1421)$ \\
0.0420 \\
$(2.6325)$ \\
0.2346 \\
$(4.3356)$ \\
0.0718 \\
$(2.8345)$ \\
0.0541 \\
$(2.7691)$ \\
-0.2487 \\
$(-2.9506)$
\end{tabular} & \begin{tabular}{|c|}
0.4390 \\
$(3.4691)$ \\
-0.1472 \\
$(-3.1321)$ \\
1.0005 \\
$(2.8281)$ \\
0.2832 \\
$(5.5322)$ \\
0.3350 \\
$(2.7299)$ \\
0.0670 \\
$(2.8477)$ \\
-0.1880 \\
$(-3.1881)$
\end{tabular} & $\begin{array}{c}0.3825 \\
(2.9431) \\
-0.0803 \\
(-2.9393) \\
0.2335 \\
(2.8713) \\
0.2128 \\
(3.1009) \\
0.0112 \\
(2.9144) \\
0.0457 \\
(2.8635) \\
-0.0023 \\
(-2.8425)\end{array}$ & \begin{tabular}{|c|}
0.0758 \\
$(2.9536)$ \\
-0.2507 \\
$(-2.8713)$ \\
1.7608 \\
$(2.8764)$ \\
0.1292 \\
$(4.7738)$ \\
1.990 \\
$(2.7953)$ \\
0.1051 \\
$(3.4975)$ \\
-0.0463 \\
$(-2.9636)$
\end{tabular} & \begin{tabular}{|c|}
0.1168 \\
$(2.9368)$ \\
-0.2676 \\
$(-3.1538)$ \\
1.5789 \\
$(2.8581)$ \\
0.1373 \\
$(4.9634)$ \\
1.8297 \\
$(2.7613)$ \\
0.1087 \\
$(3.6877)$ \\
-0.0381 \\
$(-2.9102)$
\end{tabular} & $\begin{array}{c}0.0597 \\
(2.7498) \\
-0.0559 \\
(-2.9565) \\
1.9230 \\
(2.8369) \\
0.0925 \\
(4.1412) \\
1.5474 \\
(2.9185) \\
0.0826 \\
(3.2412) \\
-0.1116 \\
(-2.8738)\end{array}$ & $\begin{array}{c}0.0171 \\
(2.9744) \\
-0.2528 \\
(-2.8492) \\
1.0024 \\
(2.8759) \\
0.2616 \\
(3.2038) \\
13.0941 \\
(3.2038) \\
0.2712 \\
(4.8230) \\
-0.3332 \\
(-2.9411)\end{array}$ & \begin{tabular}{|c|}
0.0376 \\
$(3.2888)$ \\
-0.2941 \\
$(-2.9429)$ \\
1.0714 \\
$(2.7942)$ \\
0.4124 \\
$(3.2587)$ \\
10.8246 \\
$(3.0170)$ \\
0.2233 \\
$(4.1510)$ \\
-0.1106 \\
$(-2.9870)$
\end{tabular} & \begin{tabular}{|c|}
0.3010 \\
$(2.9865)$ \\
-0.2053 \\
$(-2.9846)$ \\
0.2321 \\
$(2.9166)$ \\
0.2762 \\
$(3.3701)$ \\
4.8721 \\
$(2.7637)$ \\
0.1804 \\
$(4.1991)$ \\
-0.4605 \\
$(-2.9791)$
\end{tabular} & \begin{tabular}{|c|}
0.4555 \\
$(2.9320)$ \\
-0.0040 \\
$(-2.8654)$ \\
1.6952 \\
$(2.7952)$ \\
0.2255 \\
$(3.0763)$ \\
1.4546 \\
$(2.8461)$ \\
0.0096 \\
$(2.9401)$ \\
-0.0930 \\
$(-2.9394)$
\end{tabular} & \begin{tabular}{|c|}
0.4886 \\
$(3.3858)$ \\
-0.0335 \\
$(-2.8915)$ \\
1.5914 \\
$(2.8629)$ \\
0.2831 \\
$(3.7864)$ \\
1.8213 \\
$(2.8325)$ \\
0.0126 \\
$(2.8811)$ \\
-0.1209 \\
$(-2.9864)$
\end{tabular} & \begin{tabular}{|c|}
0.1457 \\
$(2.9316)$ \\
-0.0029 \\
$(-2.7982)$ \\
0.8473 \\
$(2.9903)$ \\
0.1514 \\
$(3.1191)$ \\
0.4563 \\
$(2.8311)$ \\
0.0753 \\
$(2.9437)$ \\
-0.2839 \\
$(-2.9559)$
\end{tabular} & \begin{tabular}{|c|}
0.1694 \\
$(3.1397)$ \\
-0.2054 \\
$(-2.9596)$ \\
1.8120 \\
$(2.8708)$ \\
0.3976 \\
$(5.8877)$ \\
0.8033 \\
$(2.8701)$ \\
0.0005 \\
$(2.9215)$ \\
-0.2857 \\
$(-2.9670)$
\end{tabular} & \begin{tabular}{|c|}
0.2811 \\
$(3.1121)$ \\
-0.1510 \\
$(-2.9126)$ \\
1.5990 \\
$(2.9422)$ \\
0.4254 \\
$(5.5711)$ \\
1.0290 \\
$(2.9256)$ \\
0.0050 \\
$(2.9211)$ \\
-0.0028 \\
$(-2.8697)$
\end{tabular} & \begin{tabular}{|c|}
0.1596 \\
$(2.9443)$ \\
-0.1951 \\
$(-2.9772)$ \\
1.3715 \\
$(2.8306)$ \\
0.3925 \\
$(5.3482)$ \\
0.9958 \\
$(2.9860)$ \\
0.0110 \\
$(2.8454)$ \\
-0.1565 \\
$(-2.9738)$
\end{tabular} & $\begin{array}{c}0.5363 \\
(3.7445) \\
-0.4289 \\
(-2.9385) \\
0.5682 \\
(2.8409) \\
0.1266 \\
(3.1494) \\
0.9221 \\
(2.9549) \\
0.0460 \\
(3.3748) \\
-0.0301 \\
(-2.9583)\end{array}$ & \begin{tabular}{|c|}
0.5509 \\
$(3.8854)$ \\
-0.4152 \\
$(-3.1020)$ \\
0.3034 \\
$(2.9219)$ \\
0.1152 \\
$(2.9384)$ \\
0.7040 \\
$(2.7812)$ \\
0.0490 \\
$(2.9466)$ \\
-0.0677 \\
$(-2.9786)$
\end{tabular} & \begin{tabular}{|c}
0.4737 \\
$(3.3240)$ \\
-0.3693 \\
$(-2.9176)$ \\
0.7281 \\
$(2.9562)$ \\
0.1126 \\
$(2.9783)$ \\
0.6100 \\
$(2.7723)$ \\
0.0586 \\
$(2.8070)$ \\
-0.1084 \\
$(-2.8638)$
\end{tabular} \\
\hline \multicolumn{19}{|c|}{ Panel B: Model Diagnostics } \\
\hline $\begin{array}{c}\text { Adjusted } R^{2} \\
\text { DW Test } \\
\chi^{2} N \\
\chi^{2} s c \\
\chi^{2} H\end{array}$ & $\begin{array}{c}0.6054 \\
2.1267 \\
0.3646 \\
{[0.8334]} \\
0.6832 \\
{[0.5138]} \\
11.4297 \\
{[0.1209]}\end{array}$ & $\begin{array}{c}0.6247 \\
2.1809 \\
0.3913 \\
{[0.8223]} \\
0.7820 \\
{[0.4680]} \\
5.7638 \\
{[0.5676]}\end{array}$ & $\begin{array}{c}0.5565 \\
2.1792 \\
0.3634 \\
{[0.8338]} \\
0.5616 \\
{[0.5771]} \\
11.3543 \\
{[0.1239]}\end{array}$ & $\begin{array}{c}0.6154 \\
2.2069 \\
0.7268 \\
{[0.6953]} \\
1.5286 \\
{[0.2357]} \\
3.9147 \\
{[0.7896]}\end{array}$ & \begin{tabular}{|c|}
0.6247 \\
2.1715 \\
0.3995 \\
{$[0.8190]$} \\
2.1435 \\
{$[0.1375]$} \\
4.1806 \\
{$[0.7588]$}
\end{tabular} & $\begin{array}{c}0.6507 \\
2.1661 \\
0.8038 \\
{[0.6690]} \\
1.0074 \\
{[0.3801]} \\
5.6342 \\
{[0.5831]}\end{array}$ & $\begin{array}{c}0.6335 \\
2.2949 \\
2.2910 \\
{[0.5244]} \\
0.6935 \\
{[0.7070]} \\
5.8134 \\
{[0.5617]}\end{array}$ & $\begin{array}{c}0.6953 \\
2.2082 \\
0.4366 \\
{[0.8034]} \\
0.8074 \\
{[0.4569]} \\
3.1477 \\
{[0.8710]}\end{array}$ & $\begin{array}{c}0.7575 \\
2.2488 \\
2.5958 \\
{[0.2731]} \\
0.6065 \\
{[0.5561]} \\
1.5026 \\
{[0.9822]}\end{array}$ & \begin{tabular}{|c|}
0.5828 \\
2.1181 \\
1.0438 \\
{$[0.5934]$} \\
1.3346 \\
{$[0.2807]$} \\
6.3093 \\
{$[0.5041]$}
\end{tabular} & \begin{tabular}{|c}
0.5404 \\
2.1911 \\
2.6440 \\
{$[0.2671]$} \\
0.9962 \\
{$[0.3829]$} \\
4.2422 \\
{$[0.7515]$}
\end{tabular} & \begin{tabular}{|c|}
0.5618 \\
2.2147 \\
1.6846 \\
{$[0.4307]$} \\
2.0913 \\
{$[0.1438]$} \\
1.2822 \\
{$[0.9889]$}
\end{tabular} & \begin{tabular}{|c|}
0.6574 \\
2.2893 \\
0.5578 \\
{$[0.7566]$} \\
0.40403 \\
{$[0.7824]$} \\
6.3893 \\
{$[0.4973]$}
\end{tabular} & $\begin{array}{c}0.6099 \\
2.2847 \\
0.9015 \\
{[0.6372]} \\
1.2670 \\
{[0.2985]} \\
4.1034 \\
{[0.7678]}\end{array}$ & $\begin{array}{c}0.6327 \\
2.2231 \\
1.4372 \\
{[0.4874]} \\
1.2341 \\
{[0.3089]} \\
5.3348 \\
{[0.6192]}\end{array}$ & $\begin{array}{c}0.5808 \\
2.2156 \\
1.1960 \\
{[0.5499]} \\
0.8292 \\
{[0.4476]} \\
3.8458 \\
{[0.7974]}\end{array}$ & \begin{tabular}{|c|}
0.5926 \\
2.1636 \\
1.3359 \\
{$[0.5312]$} \\
0.6592 \\
{$[0.5257]$} \\
8.5920 \\
{$[0.2833]$}
\end{tabular} & \begin{tabular}{|c}
0.5968 \\
2.2076 \\
1.1500 \\
{$[0.5627]$} \\
0.3355 \\
{$[0.7189]$} \\
11.5745 \\
{$[0.1154]$}
\end{tabular} \\
\hline
\end{tabular}

Notes: AT, BE, FI, FR, GE and NL stand for Austria, Belgium, Finland, France, Germany and the Netherlands respectively, while $h d$, $c d$ and $p d$ stand for household, corporate and public debt respectively. See Appendix 1 for a definition of the variables and the text for the specification of the estimated model.

In the ordinary brackets below the parameter estimates, the corresponding t-statistics are shown, based on the small-sample degree of-freedom corrected, heteroskedasticity and autocorrelation consistent standard errors proposed by Newey and West (1987).

$\chi^{2} \mathrm{~N}, \chi^{2} \mathrm{sc}$ and $\chi^{2} \mathrm{H}$ are the Jarque-Bera test for normality, the Breusch-Godfrey LM test for second-order serial correlation and the Breusch-Pagan-Godfrey test for heteroskedasticity. The associated probability values are given in square brackets. 
Table 2b. Baseline empirical model. Peripheral countries.

\begin{tabular}{|c|c|c|c|c|c|c|c|c|c|c|c|c|}
\hline \multicolumn{10}{|c|}{ Panel A: Estimation results } & \\
\hline & \multicolumn{3}{|c|}{ GR } & \multicolumn{3}{|c|}{ IT } & \multicolumn{3}{|c|}{ PT } & \multicolumn{3}{|c|}{ SP } \\
\hline & hd & $c d$ & $p d$ & $h d$ & $c d$ & $p d$ & $h d$ & $c d$ & $p d$ & $h d$ & $c d$ & $p d$ \\
\hline \multirow[t]{2}{*}{$g_{t-1}$} & 0.6952 & 0.6638 & 0.4374 & 0.2579 & 0.2969 & 0.1781 & 0.4654 & 0.5313 & 0.2934 & 0.7765 & 0.8557 & 0.4335 \\
\hline & (3.9309) & (4.1203) & (2.9916) & $(2.8508)$ & (2.9651) & (2.9111) & (2.9918) & (3.4383) & $(2.9513)$ & (3.1404) & $(3.3086)$ & (2.9349) \\
\hline \multirow[t]{2}{*}{$I N F_{t}$} & -0.3243 & -0.2594 & -0.2198 & -0.0011 & -0.0105 & -0.0471 & -0.1321 & -0.1062 & -0.0528 & -0.0481 & -0.0767 & -0.0219 \\
\hline & $(-2.9755)$ & $(-2.8716)$ & $(-2.7857)$ & $(-2.8693)$ & $(2.9160)$ & $(-2.8709)$ & $(-2.8727)$ & $(-2.7673)$ & $(-2.8067)$ & $(-2.9797)$ & $(-2.9282)$ & $(-2.8386)$ \\
\hline \multirow[t]{2}{*}{$\triangle O P E N_{t}$} & 0.0137 & 0.0625 & 0.0114 & 0.2369 & 0.2395 & 0.1891 & 0.1428 & 0.1463 & 0.1210 & 0.2294 & 0.2754 & 0.1218 \\
\hline & $(2.7124)$ & $(2.7536)$ & $(2.7110)$ & $(2.7934)$ & $(2.8679)$ & $(2.8270)$ & $(2.7510)$ & $(2.7542)$ & $(2.7586)$ & (2.7387) & $(2.7215)$ & (2.7513) \\
\hline \multirow{2}{*}{ POPGRO $_{t}$} & 1.7489 & 1.1643 & 1.8628 & 2.3133 & 2.1702 & 2.0588 & 1.4095 & 0.5896 & 0.0080 & 0.3932 & 0.1454 & 0.7608 \\
\hline & $(2.9646)$ & $(2.6804)$ & $(2.7968)$ & $(2.7567)$ & $(2.8721)$ & $(2.8929)$ & $(2.9681)$ & (2.8535) & $(2.7622)$ & (2.7684) & $(2.8304)$ & $(2.8312)$ \\
\hline \multirow{2}{*}{$G S_{t}$} & 0.1952 & 0.1448 & 0.1434 & 0.0430 & 0.0451 & 0.0545 & 0.1306 & 0.0980 & 0.1167 & 0.0436 & 0.0371 & 0.1205 \\
\hline & (3.1206) & $(2.6441)$ & $(2.8193)$ & $(2.7352)$ & $(2.7419)$ & $(2.8175)$ & $(2.9616)$ & (2.9185) & (3.3047) & $(2.8451)$ & $(2.7623)$ & $(2.7473)$ \\
\hline \multirow[t]{2}{*}{$\Delta d_{t}$} & -0.5350 & -0.3390 & -0.1434 & -0.1768 & -0.0767 & -0.1502 & -0.2175 & -0.1593 & -0.2279 & -0.1444 & -0.1826 & -0.2050 \\
\hline & $(-2.9417)$ & $(-2.8192)$ & $(-2.8576)$ & $(-2.8635)$ & $(-2.9115)$ & $(-2.8552)$ & $(-2.9244)$ & $(-2.9221)$ & $(-3.1441)$ & $(-2.9745)$ & $(-2.8794)$ & $(-2.7208)$ \\
\hline \multicolumn{13}{|c|}{ Panel B: Model Diagnostics } \\
\hline \multirow{4}{*}{$\begin{array}{c}\text { Adjusted } R^{2} \\
\text { DW Test } \\
\chi^{2} N\end{array}$} & 0.5700 & 0.6180 & 0.6321 & 0.5939 & 0.6028 & 0.6134 & 0.5928 & 0.6289 & 0.6377 & & & \\
\hline & 2.2119 & 2.1480 & 2.1987 & 2.3144 & 2.2578 & 2.3077 & 2.2578 & 2.2229 & 2.2791 & $\begin{array}{l}0.6293 \\
2.1571\end{array}$ & $\begin{array}{l}0.6365 \\
2.1446\end{array}$ & $\begin{array}{l}0.69 / 9 \\
2.2499\end{array}$ \\
\hline & 0.7694 & 0.1594 & 0.4905 & 0.2095 & 0.3395 & 0.1880 & 0.3395 & 0.7712 & 0.3485 & $\begin{array}{l}2.7129 \\
1.7129\end{array}$ & 0.7618 & 1.7816 \\
\hline & [0.6809] & [0.9234] & {$[0.7825]$} & [0.9006] & {$[0.8438]$} & [0.9131] & [0.8438] & [0.6801] & [0.8401] & [0.4249] & [0.6833] & [0.4144] \\
\hline \multirow[t]{2}{*}{$\chi^{2} s C$} & 0.3660 & 0.7903 & 0.7345 & 1.9360 & 3.2863 & 1.4282 & 3.2863 & 0.1957 & 0.9953 & 1.0187 & 1.2034 & 2.3961 \\
\hline & [0.6970] & [0.4643] & [0.4894] & [0.1645] & {$[0.2212]$} & {$[0.2594]$} & {$[0.2212]$} & {$[0.8235]$} & {$[0.3833]$} & {$[0.3750]$} & {$[0.3163]$} & {$[0.1109]$} \\
\hline \multirow[t]{2}{*}{$\chi^{2} H$} & $\begin{array}{c}3.8231 \\
{[07999]}\end{array}$ & $\begin{array}{r}4.8579 \\
\end{array}$ & 7.6662 & 6.6320 & 6.0811 & 6.4324 & 6.0811 & 3.8070 & 6.9531 & 9.6066 & 7.1328 & 9.3144 \\
\hline & & & {$[0.3629]$} & {$[0.4682]$} & {$[0.5303]$} & {$[0.4903]$} & {$[0.5303]$} & {$[0.8017]$} & {$[0.4338]$} & {$[0.2120]$} & [0.4152] & {$[0.2309]$} \\
\hline
\end{tabular}

See $\mathrm{A}, \mathrm{FR}, \mathrm{GE}$ and NL stand for Austria, Belgium, Finland, France, Germany and the Netherlands respectively, while $h d, c d$ and $p d$ stand for household, corporate and public debt respectively.

In the ordinary brackets below the parameter estimates, the corresponding t-statistics are shown, based on the small-sample degree of-freedom corrected, heteroskedasticity and autocorrelation consistent standard errors proposed by Newey and West (1987).

$\chi^{2} \mathrm{~N}, \chi^{2} \mathrm{sc}$ and $\chi^{2} \mathrm{H}$ are the Jarque-Bera test for normality, the Breusch-Godfrey LM test for second-order serial correlation and the Breusch-Pagan-Godfrey test for heteroskedasticity. The associated probability values are given in square brackets. 
Table 3a. Asymmetric model. Central countries

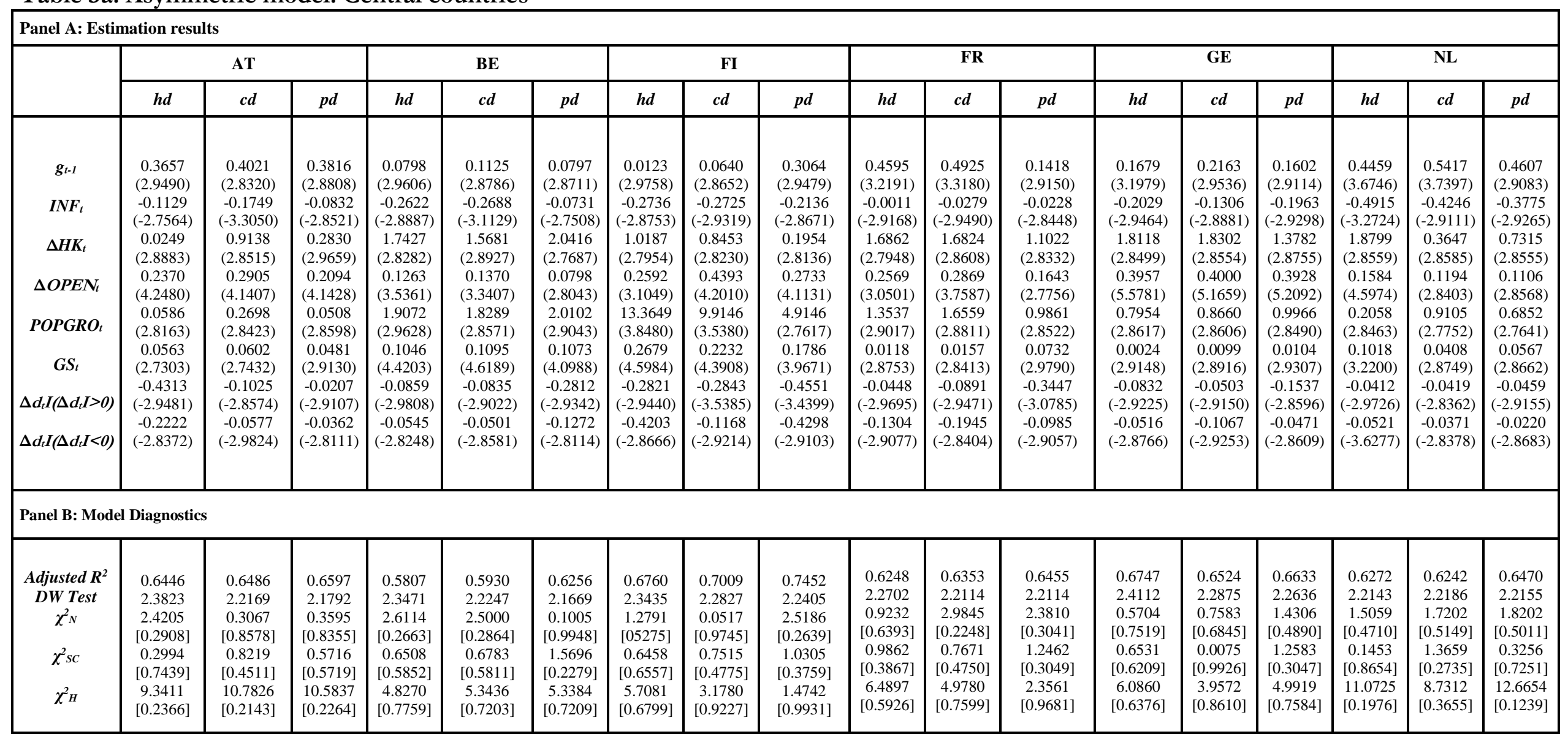

Notes: AT, BE, FI, FR, GE and NL stand for Austria, Belgium, Finland, France, Germany and the Netherlands respectively, while $h d$, $c d$ and $p d$ stand for household, corporate and public debt respectively.

See Appendix 1 for a definition of the variables and the text for the specification of the estimated model.

In the ordinary brackets below the parameter estimates, the corresponding t-statistics are shown, based on the small-sample degree of-freedom corrected, heteroskedasticity and autocorrelation consistent standard errors proposed by Newey and West (1987).

$\chi^{2} \mathrm{~N}, \chi_{\mathrm{SC}}^{2}$ and $\chi^{2} \mathrm{H}$ are the Jarque-Bera test for normality, the Breusch-Godfrey LM test for second-order serial correlation and the Breusch-Pagan-Godfrey test for heteroskedasticity. The associated probability values are given in square brackets. 
Table 3b. Asymmetric model. Peripheral countries.

\begin{tabular}{|c|c|c|c|c|c|c|c|c|c|c|c|c|}
\hline \multicolumn{13}{|c|}{ Panel A: Estimation results } \\
\hline & \multicolumn{3}{|c|}{ GR } & \multicolumn{3}{|c|}{ IT } & \multicolumn{3}{|c|}{ PT } & \multicolumn{3}{|c|}{ SP } \\
\hline & $h d$ & $c d$ & $p d$ & $h d$ & $c d$ & $p d$ & $h d$ & $c d$ & $p d$ & $h d$ & $c d$ & $p d$ \\
\hline \multirow[t]{2}{*}{$g_{t-1}$} & 0.5992 & 0.6534 & 0.1392 & 0.2557 & 0.2899 & 0.1323 & 0.4766 & 0.5790 & 0.3119 & 0.8802 & 0.8926 & 0.4381 \\
\hline & $(2.9723)$ & $(2.9536)$ & $(2.9325)$ & $(2.8257)$ & (2.8777) & $(2.8218)$ & (3.0387) & (2.9794) & (2.9110) & (3.0305) & $(3.0503)$ & $(2.8850)$ \\
\hline \multirow[t]{2}{*}{$I N F_{t}$} & -0.3849 & -0.2755 & -0.3450 & -0.0104 & -0.0158 & -0.0346 & -0.1370 & -0.1109 & -0.0674 & -0.0114 & -0.1419 & -0.0285 \\
\hline & $(-3.1451)$ & $(-2.7661)$ & $(-2.9123)$ & $(-2.7827)$ & $(-2.8912)$ & $(-2.7526)$ & $(-2.9267)$ & $(-2.9698)$ & $(-2.7836)$ & $(-2.9152)$ & $(-2.9268)$ & $(-2.8435)$ \\
\hline \multirow[t]{2}{*}{$\Delta H K_{t}$} & 0.3057 & 0.1226 & 0.1514 & 0.7764 & 1.5046 & 0.9579 & 1.0638 & 0.8110 & 0.2826 & 0.7905 & 0.9224 & 1.2093 \\
\hline & $(2.7545)$ & (2.8327) & $(2.8514)$ & (2.7573) & $(2.7722)$ & $(2.8658)$ & (2.9088) & $(2.7454)$ & $(2.7427)$ & (2.7667) & $(2.8269)$ & (2.9189) \\
\hline \multirow[t]{2}{*}{$\triangle O P E N_{t}$} & 0.0108 & 0.1139 & 0.0120 & 0.2613 & 0.2313 & 0.1879 & 0.1517 & 0.1628 & 0.1237 & 0.1974 & 0.2847 & 0.1221 \\
\hline & (2.7099) & (2.9499) & $(2.7406)$ & (3.5372) & (2.8518) & $(2.9468)$ & (2.7659) & $(2.8269)$ & (2.8510) & (2.8723) & $(3.0860)$ & (2.7902) \\
\hline \multirow[t]{2}{*}{ POPGROt $_{t}$} & 1.4382 & 1.6757 & 1.8957 & 2.3696 & 2.2084 & 2.2395 & 1.2213 & 0.6516 & 0.0031 & 0.3964 & 0.1359 & 0.7131 \\
\hline & $(2.8082)$ & (2.9766) & (2.8381) & $(2.7549)$ & $(2.8053)$ & (2.8313) & $(2.8256)$ & $(2.7632)$ & (2.7428) & $(2.7170)$ & (2.8776) & $(2.8489)$ \\
\hline \multirow[t]{2}{*}{$G S_{t}$} & 0.2585 & 0.1714 & 0.2795 & 0.0642 & 0.0366 & 0.0873 & 0.1462 & 0.0577 & 0.1376 & 0.0050 & 0.0191 & 0.1240 \\
\hline & (3.1210) & (2.8916) & (2.9548) & $(2.7266)$ & (2.9189) & $(2.8239)$ & $(2.7403)$ & $(2.8405)$ & (3.8611) & (2.8124) & (2.7189) & (3.3650) \\
\hline \multirow{2}{*}{$\Delta d_{t} I\left(\Delta d_{t} I>0\right)$} & -0.5137 & -0.3900 & -0.2763 & -0.2561 & -0.1737 & -0.2400 & -0.2666 & -0.0870 & -0.2828 & -0.1924 & -0.0981 & -0.1129 \\
\hline & $(-2.8232)$ & $(-2.9150)$ & $(-2.9596)$ & $(-2.9234)$ & $(-2.8325)$ & $(-2.9501)$ & $(-2.9443)$ & $(-2.7413)$ & $(-3.5280)$ & $(-2.9296)$ & $(-2.7754)$ & $(-3.1691)$ \\
\hline \multirow{2}{*}{$\Delta d_{t} I\left(\Delta d_{t} I<0\right)$} & -0.4800 & -0.0033 & -0.0526 & -0.1878 & -0.0751 & -0.1760 & -0.4112 & -0.0706 & -0.1343 & -0.7396 & -0.0728 & -0.0376 \\
\hline & $(-2.7953)$ & $(-2.8117)$ & $(-2.8463)$ & $(-3.2643)$ & $(-2.8960)$ & $(-2.8649)$ & $(-2.8545)$ & $(-2.8561)$ & $(-2.8546)$ & $(-2.8585)$ & $(-2.9720)$ & $(-2.9599)$ \\
\hline \multicolumn{13}{|c|}{ Panel B: Model Diagnostics } \\
\hline Adjusted $R^{2}$ & 0.5824 & 0.6550 & 0.7370 & 0.6628 & 0.6021 & 0.6201 & 0.6121 & 0.6543 & 0.6647 & 0.6136 & 0.6395 & 0.6873 \\
\hline DW Test & 2.3108 & 2.2684 & 2.2910 & 2.2083 & 2.2837 & 2.3025 & 2.2117 & 2.1382 & 2.1709 & 2.3208 & 2.1564 & 2.2221 \\
\hline \multirow{2}{*}{$\chi^{2} N$} & 0.7340 & 0.1803 & 1.3648 & 0.2160 & 0.9752 & 0.5109 & 0.5135 & 1.4850 & 2.4805 & 0.1092 & 1.4116 & 1.4624 \\
\hline & {$[0.6928]$} & [0.9138] & {$[0.5054]$} & [0.8976] & {$[0.6138]$} & {$[0.7746]$} & {$[0.7736]$} & [0.4759] & {$[0.2893]$} & [0.9469] & [0.4937] & [0.5637] \\
\hline \multirow[t]{2}{*}{$\chi^{2} s c$} & 0.3257 & 0.5302 & 1.6182 & 1.7222 & 1.6267 & 1.0837 & 0.4286 & 0.3776 & 0.5417 & 0.0938 & 1.2985 & 0.9362 \\
\hline & {$[0.7251]$} & {$[0.7203]$} & {$[0.2183]$} & [0.1992] & {$[0.2167]$} & {$[0.3550]$} & {$[0.6561]$} & [0.8312] & {$[0.5941]$} & {$[0.9108$} & [0.2907] & [0.4086] \\
\hline \multirow[t]{2}{*}{$\chi^{2} H$} & 4.5151 & 4.9322 & 0.6884 & 6.7924 & 5.9522 & 4.4272 & 5.0263 & 4.2221 & 8.6515 & 7.4995 & 2.9953 & 8.8562 \\
\hline & [0.8070] & {$[0.7648]$} & [0.9996] & [0.5592] & {$[0.6526]$} & [0.8167] & {$[0.7548]$} & {$[0.8365]$} & {$[0.2725]$} & {$[0.4838]$} & {$[0.9347]$} & {$[0.3546]$} \\
\hline
\end{tabular}

Notes: AT, BE, FI, FR, GE and NL stand for Austria, Belgium, Finland, France, Germany and the Netherlands respectively, while $h d$, $c d$ and $p d$ stand for household, corporate and public debt respectively.

See Appendix 1 for a definition of the variables and the text for the specification of the estimated model.

In the ordinary brackets below the parameter estimates, the corresponding t-statistics are shown, based on the small-sample degree of-freedom corrected, heteroskedasticity and autocorrelation consistent standard errors proposed by Newey and West (1987).

$\chi^{2} \mathrm{~N}, \chi^{2} \mathrm{sc}$ and $\chi^{2} \mathrm{H}$ are the Jarque-Bera test for normality, the Breusch-Godfrey LM test for second-order serial correlation and the Breusch-Pagan-Godfrey test for heteroskedasticity. The associated probability values are given in square brackets. 
Table 4a. Threshold model. Central countries.

\begin{tabular}{|c|c|c|c|c|c|c|c|c|c|c|c|c|c|c|c|c|c|c|}
\hline \multicolumn{19}{|c|}{ Panel A: Estimation results } \\
\hline & \multicolumn{3}{|c|}{ AT } & \multicolumn{3}{|c|}{ BE } & \multicolumn{3}{|c|}{ FI } & \multicolumn{3}{|c|}{$\begin{array}{l}\mathbf{F R} \\
\end{array}$} & \multicolumn{3}{|c|}{ GE } & \multicolumn{3}{|c|}{ NL } \\
\hline & $h d$ & $c d$ & $p d$ & hd & $c d$ & $p d$ & hd & $c d$ & $p d$ & hd & $c d$ & $p d$ & hd & $c d$ & $p d$ & hd & $c d$ & $p d$ \\
\hline \multirow[b]{3}{*}{$I N F t$} & 3812 & 0.4619 & 0.3980 & 0.0826 & .1164 & 0.1468 & 0.0060 & 0.0349 & 0.2867 & 0.4901 & 0.3768 & 0.1592 & 0.1382 & 0.2537 & 0.0676 & 0.548 & 0.5662 & 0.4578 \\
\hline & (2.9578) & $(3.5729)$ & (2.8935) & $(2.9650)$ & $(2.9329)$ & $(2.9207)$ & $(2.9711)$ & (2.9264) & $(2.8979)$ & (3.3965) & $(2.9565)$ & $(2.9171)$ & (3.1128) & (2.8757) & (2.9189) & (3.7974) & (3.9266) & (3.3624) \\
\hline & -0.1579 & -0.1228 & -0.1701 & -0.2059 & -0.2556 & -0.1151 & -0.3094 & -0.3033 & -0.2321 & -0.0713 & -0.0368 & -0.1219 & -0.2243 & -0.1509 & -0.2085 & -0.3287 & -0.4401 & -0.4506 \\
\hline \multirow{3}{*}{$\Delta H K t$} & $(-2.9175)$ & $(-2.9232)$ & $(-2.8547)$ & $(-2.8615)$ & $(-2.9776)$ & $(-2.8376)$ & $(-2.8842)$ & $(-2.9407)$ & $(-2.8635)$ & $(-2.8191)$ & $(-2.8378)$ & $(-2.8480)$ & $(-2.9366)$ & $(-2.9003)$ & $(-2.9701)$ & $(-2.9541)$ & $(-2.9183)$ & $(-2.9487)$ \\
\hline & 1.0575 & 1.1273 & 0.6369 & 1.5200 & 1.4224 & 1.7559 & 0.8464 & 1.0339 & 0.0700 & 1.7175 & 1.6387 & 0.9103 & 2.0515 & 1.7604 & 1.6316 & 0.7420 & 0.0409 & 0.8853 \\
\hline & $(2.8491)$ & $(2.8247)$ & (2.9444) & (2.8730) & (2.8646) & $(2.7655)$ & $(2.7860)$ & (2.8702) & (2.8496) & $(2.8853)$ & $(2.8510)$ & (2.8106) & (2.9170) & (2.9799) & (2.9344) & (2.7527) & (2.8476) & $(2.8715)$ \\
\hline \multirow{2}{*}{$\triangle O P E N t$} & 0.2201 & 0.2860 & 0.2524 & 0.1326 & 0.1350 & 0.1005 & 0.2582 & 0.4096 & 0.2632 & 0.2517 & 0.2409 & 0.1602 & 0.3854 & 0.4122 & 0.3980 & 0.1377 & 0.1223 & 0.1179 \\
\hline & (4.4324) & $(4.5622)$ & (3.5412) & (2.9958) & (3.8539) & (3.2. & (3.1223) & (4.2784) & $(4.1254)$ & (3.5592) & (3.1871) & (2.8723) & (5.6486) & (5.1063) & (3.9811) & (3.2575) & (2.8468) & $(3.2622)$ \\
\hline \multirow[t]{2}{*}{ POPGROt } & 0.0386 & 0.0774 & 0.7719 & 1.7896 & 1.6550 & 1.5868 & 13.3835 & 10.9080 & 4.9110 & 1.0355 & 1.6401 & 0.0882 & 0.8180 & 0.9903 & 0.8069 & 0.2997 & 0.8598 & 0.7978 \\
\hline & (2.8646) & $(2.7838)$ & (2.8561) & (2.8434) & (2.7783) & $(2.8359)$ & (3.9879) & (3.9674) & (2.7667) & (2.7924) & $(2.8374)$ & (2.7586) & (2.8716) & (2.8696) & (2.7638) & (2.8640) & (2.9459) & $(2.7516)$ \\
\hline \multirow[t]{2}{*}{$G S t$} & 0.0411 & 0.0622 & 0.0431 & 0.0990 & 0.1059 & 0.0829 & 0.2690 & 0.2224 & 0.1733 & 0.0018 & 0.0033 & 0.0889 & 0.0006 & 0.0060 & 0.0022 & 0.0469 & 0.0454 & 0.0642 \\
\hline & $(2.8945)$ & $(2.7524)$ & (2.8156) & $(4.2681)$ & (4.5304) & $(3.4266)$ & $(4.7280)$ & (5.0413) & (4.0169) & $(2.8179)$ & (2.8937) & $(2.8341)$ & (2.9287) & $(2.8250)$ & (2.9583) & (2.8394) & (2.8733) & (2.8695) \\
\hline \multirow{2}{*}{$\Delta d t I\left(d t>d^{*}\right)$} & -0.2771 & -0.2113 & -0.0524 & -0.2635 & -0.0549 & -0.0341 & -0.5172 & -0.5295 & -0.4311 & -0.2782 & -0.2908 & -0.2864 & -0.1355 & -0.0211 & -0.1770 & -0.0337 & -0.0748 & -0.2592 \\
\hline & $(-2.9968)$ & $(-3.2864)$ & $(-2.9410)$ & $(-2.9614)$ & $(-2.8420)$ & $(-2.8473)$ & $(-2.8879)$ & $(-3.7953)$ & $(-3.3641)$ & $(-2.8735)$ & $(-2.9307)$ & $(-3.6270)$ & $(-2.8793)$ & $(-2.9365)$ & $(-2.9165)$ & $(-2.9461)$ & $(-2.8782)$ & $(-2.9513)$ \\
\hline$\Delta d t I\left(d t<d^{*}\right)$ & 0.1290 & $\begin{array}{r}0.0542 \\
(28612)\end{array}$ & 0.0398 & $\begin{array}{c}0.0965 \\
0\end{array}$ & 0.0066 & 0.0061 & 0.3080 & 0.2433 & 0.2408 & 0.1466 & 0.0570 & 0.0487 & 0.0936 & 0.0280 & 0.0571 & 0.3754 & 0.0230 & 0.0218 \\
\hline$d^{*}$ & $39 \%$ & $65 \%$ & $60 \%$ & $40 \%$ & $110 \%$ & $96 \%$ & $34 \%$ & $105 \%$ & $40 \%$ & $40 \%$ & $135 \%$ & $35 \%$ & $65 \%$ & $60 \%$ & $40 \%$ & $47 \%$ & $102 \%$ & $60 \%$ \\
\hline \multicolumn{19}{|c|}{ Panel B: Model Diagnostics } \\
\hline \multirow{4}{*}{$\begin{array}{c}\text { Adjusted } R^{2} \\
D W T \text { Test } \\
\chi^{2}{ }^{2}\end{array}$} & 0.673 & 0.6641 & 0.6816 & 0.6662 & 0.5728 & 0.6678 & 0.6778 & 0.7411 & 0.7571 & 0.6767 & 0.5873 & 0.6786 & 0.6979 & 0.6632 & 0.6773 & 0.6588 & 0.6239 & 0.6454 \\
\hline & 2.2078 & 2.1265 & 2.1861 & 2.3727 & 2.1528 & 2.1871 & 2.4117 & 2.2471 & 2.2131 & 2.2754 & 2.2233 & 2.1881 & 2.3312 & 2.2093 & 2.2112 & 2.2363 & 2.2180 & 2.2164 \\
\hline & 0.9964 & 1.4591 & 0.2813 & 0.6388 & 0.7440 & 0.9011 & 0.7667 & 0.0397 & 2.2067 & 1.2756 & 1.7358 & 2.0208 & 0.7933 & 0.9080 & 1.0586 & 0.6652 & 0.7351 & 0.7813 \\
\hline & {$[0.6076]$} & {$[0.4821]$} & {$[0.8688]$} & [0.7283] & {$[0.6833]$} & {$[0.6373]$} & {$[0.6867]$} & [0.9804] & {$[0.3318]$} & {$[0.5285]$} & {$[0.4198]$} & {$[0.3841]$} & {$[0.6726]$} & {$[0.6351]$} & {$[0.5890]$} & {$[0.6357]$} & {$[0.6517]$} & {$[0.64111$} \\
\hline \multirow[t]{2}{*}{$\chi^{2} s c$} & 0.6195 & 0.4473 & 0.4990 & 1.1391 & 2.2545 & 1.8948 & 0.6297 & 0.5488 & 1.5578 & 1.4275 & 0.9418 & 1.0884 & 1.0565 & 1.1253 & 0.7799 & 1.1263 & 1.2661 & 1.0447 \\
\hline & {$[0.5463]$} & {$[0.6444]$} & {$[0.6130]$} & {$[0.3362]$} & {$[0.2287]$} & {$[0.1713]$} & [0.6924] & {$[0.5844]$} & {$[0.2392]$} & {$[0.2588]$} & [0.4033] & {$[0.3522]$} & {$[0.3534]$} & {$[0.3404]$} & {$[0.4693]$} & {$[0.3401]$} & [0.3009] & {$[0.3667]$} \\
\hline \multirow[t]{2}{*}{$\chi^{2} H$} & 4.7135 & 9.0544 & 7.7119 & 4.4394 & 5.8618 & 3.2244 & 7.6402 & 3.0921 & 1.6446 & 6.3419 & 4.8857 & 0.9549 & 6.8825 & 4.1841 & 3.3197 & 10.5322 & 7.9127 & 11.9384 \\
\hline & & & {$[0$} & & & & & & & {$[0.66$} & & & & & & {$[0$.} & {$[0.4$} & {$[0.2168]$} \\
\hline
\end{tabular}

Notes: AT, BE, FI, FR, GE and NL stand for Austria, Belgium, Finland, France, Germany and the Netherlands respectively, while $h d$, $c d$ and $p d$ stand for household, corporate and public debt respectively.

See Appendix 1 for a definition of the variables and the text for the specification of the estimated model.

In the ordinary brackets below the parameter estimates, the corresponding t-statistics are shown, based on the small-sample degree of-freedom corrected, heteroskedasticity and autocorrelation consistent standard errors proposed by Newey and West (1987).

$\chi^{2} \mathrm{~N}, \chi^{2} \mathrm{sc}$ and $\chi^{2} \mathrm{H}$ are the Jarque-Bera test for normality, the Breusch-Godfrey LM test for second-order serial correlation and the Breusch-Pagan-Godfrey test for heteroskedasticity. The associated probability values are given in square brackets. 
Table 4b. Threshold model. Peripheral countries.

\begin{tabular}{|c|c|c|c|c|c|c|c|c|c|c|c|c|}
\hline \multicolumn{13}{|c|}{ Panel A: Estimation results } \\
\hline & \multicolumn{3}{|c|}{ GR } & \multicolumn{3}{|c|}{ IT } & \multicolumn{3}{|c|}{ PT } & \multicolumn{3}{|c|}{$\overline{\text { SP }}$} \\
\hline & hd & $c d$ & $p d$ & hd & $c d$ & $p d$ & hd & $c d$ & $p d$ & hd & $c d$ & $p d$ \\
\hline & $\begin{array}{c}0.6956 \\
(3.8584)\end{array}$ & $\begin{array}{c}0.7073 \\
(4.4791)\end{array}$ & $\begin{array}{c}0.4205 \\
(2.7976)\end{array}$ & $\begin{array}{c}0.1655 \\
(28455)\end{array}$ & $\begin{array}{c}0.2471 \\
(2.9131)\end{array}$ & $\begin{array}{c}0.2426 \\
(28477)\end{array}$ & $\begin{array}{c}0.4581 \\
(2.9148)\end{array}$ & $\begin{array}{c}0.4709 \\
(2.9488)\end{array}$ & $\begin{array}{c}0.3036 \\
(2.9465)\end{array}$ & $\begin{array}{c}0.8802 \\
(3.0305)\end{array}$ & $\begin{array}{c}0.8533 \\
(3.1630)\end{array}$ & $\begin{array}{c}0.3218 \\
(2.8527)\end{array}$ \\
\hline \multirow[t]{2}{*}{$I N F_{t}$} & -0.3282 & -0.2385 & -0.3245 & -0.0572 & -0.0292 & -0.0900 & -0.1163 & -0.0950 & -0.0120 & -0.0114 & -0.0890 & -0.1132 \\
\hline & $(-2.7342)$ & $(-2.7425)$ & $(-2.9230)$ & $(-2.7762)$ & $(-2.8405)$ & $(-2.8888)$ & $(-2.8568$ & $(-2.8398)$ & $(-2.7699)$ & $(-2.9152)$ & $(-2.9202)$ & $(-2.7810)$ \\
\hline \multirow[t]{2}{*}{$\Delta H K_{t}$} & 0.5166 & 0.4972 & 0.1976 & 1.0427 & 1.3297 & 1.0141 & 0.8297 & 1.0094 & 0.0863 & 0.7905 & 0.7258 & 1.2688 \\
\hline & $(2.7251)$ & $(2.7249)$ & $(2.8103)$ & (2.7648) & $(2.9124)$ & (2.7499) & (2.7768) & $(2.7957)$ & $(2.8133)$ & $(2.7667)$ & $(2.8614)$ & (2.7901) \\
\hline \multirow{2}{*}{$\triangle O P E N_{t}$} & 0.0133 & 0.0462 & 0.0044 & 0.3049 & 0.2144 & 0.2509 & 0.1279 & 0.1281 & 0.1374 & 0.1974 & 0.3062 & 0.1490 \\
\hline & $(2.8119)$ & (2.7408) & $(2.7847)$ & $(4.1812)$ & $(2.8369)$ & (3.1804) & $(2.7312)$ & (2.7735) & 2.7649) & $(2.8723)$ & (3.0701) & $(2.0466)$ \\
\hline \multirow[t]{2}{*}{ POPGRO $_{t}$} & 1.7723 & 1.8452 & 2.7994 & 1.8146 & 2.2311 & 1.5816 & 1.2847 & 0.6516 & 0.3953 & 0.3964 & 0.1754 & 0.4447 \\
\hline & $(2.9354)$ & $(2.8378)$ & $(2.7619)$ & $(2.7612)$ & $(2.8268)$ & $(2.7537)$ & $(2.8695)$ & $(2.7598)$ & $(2.7449)$ & $(2.7170)$ & $(2.7349)$ & $(2.7594)$ \\
\hline \multirow[t]{2}{*}{$G S_{t}$} & 0.1976 & 0.1094 & 0.1529 & 0.0168 & 0.0358 & 0.0596 & 0.1256 & 0.0911 & 0.0949 & 0.0050 & 0.0355 & 0.1465 \\
\hline & $(2.7586)$ & $(2.9228)$ & $(2.9539)$ & $(2.7613)$ & (2.8988) & $(2.9162)$ & $(2.9472)$ & (2.8323) & $(2.8475)$ & $(2.8124)$ & $(2.8211)$ & (2.9624) \\
\hline \multirow[t]{2}{*}{$\Delta d t I\left(d t>d^{*}\right)$} & -0.7607 & -0.5550 & -0.1440 & -0.2172 & -0.1842 & -0.2821 & -0.1764 & -0.1738 & -0.2074 & -0.1924 & -0.1846 & -0.2970 \\
\hline & $(-2.9171)$ & $(-2.8235)$ & $(-2.9542)$ & $(-2.9741)$ & $(-2.9172)$ & $(-2.9449)$ & $(-2.9543)$ & $(-2.8508)$ & $(-2.9400)$ & $(-2.9296)$ & $(-2.9342)$ & $(-2.9764)$ \\
\hline$\Delta d t I\left(d t<d^{*}\right)$ & $\begin{array}{c}0.5346 \\
(2.8994)\end{array}$ & $\begin{array}{c}0.0580 \\
(2.7648)\end{array}$ & $\begin{array}{c}0.0464 \\
(2.8711)\end{array}$ & $\begin{array}{c}0.1987 \\
(3.7289)\end{array}$ & $\begin{array}{c}0.1301 \\
(2.8578)\end{array}$ & $\begin{array}{c}0.1097 \\
(2.8614)\end{array}$ & $\begin{array}{c}0.3889 \\
(2.8335)\end{array}$ & $\begin{array}{c}0.2181 \\
(2.7654)\end{array}$ & $\begin{array}{c}0.0296 \\
(2.8110)\end{array}$ & $\begin{array}{c}0.7396 \\
(2.8585)\end{array}$ & $\begin{array}{c}0.2248 \\
(2.8698)\end{array}$ & $\begin{array}{c}0.0313 \\
(2.8763)\end{array}$ \\
\hline$d^{*}$ & $32 \%$ & $52 \%$ & $71 \%$ & $19 \%$ & $61 \%$ & $90 \%$ & $33 \%$ & $80 \%$ & $50 \%$ & $40 \%$ & $95 \%$ & $50 \%$ \\
\hline \multicolumn{13}{|c|}{ Panel B: Model Diagnostics } \\
\hline & 0.6316 & 0.6824 & 0.7103 & 0.6112 & 0.6404 & 0.6714 & 0.6415 & 0.6762 & 0.6762 & 0.6568 & 0.6607 & 0.7887 \\
\hline DW Test & 2.3005 & 2.1822 & 2.1493 & 2.2567 & 2.2311 & 2.2381 & 2.3691 & 2.2233 & 2.2191 & 2.3149 & 2.2845 & 2.2153 \\
\hline \multirow{2}{*}{$\begin{array}{c}D W 1 \text { est } \\
\chi^{2} N\end{array}$} & 2.2877 & 0.7561 & 0.0312 & 2.5389 & 0.3742 & 1.1246 & 0.7757 & 0.0647 & 0.1476 & 0.7465 & 1.1876 & 1.0470 \\
\hline & {$[0.3186]$} & {$[0.6852]$} & {$[0.9845]$} & {$[0.2810]$} & [0.8294] & {$[0.5448]$} & {$[0.6785]$} & [0.9682] & {$[0.9289]$} & [0.6996] & {$[0.5612]$} & [0.5925] \\
\hline \multirow[t]{2}{*}{$\chi^{2} s c$} & 0.8302 & 1.6307 & 0.4180 & 1.6747 & 0.8491 & 1.5284 & 0.3948 & 1.0446 & 1.0446 & 0.7698 & 0.7427 & 0.7515 \\
\hline & {$[0.4476]$} & [0.2159] & [0.6629] & [0.2077] & {$[0.4398]$} & {$[0.2365]$} & [0.6779] & {$[0.3667]$} & {$[0.3667]$} & {$[0.4738]$} & {$[0.4861]$} & [0.4833] \\
\hline \multirow[t]{2}{*}{$\chi^{2} H$} & 6.2949 & 3.1782 & 7.6419 & 3.7351 & 5.8636 & 6.8805 & 7.5708 & 3.0960 & 3.0960 & 6.4329 & 3.4514 & 3.8619 \\
\hline & {$[0.6142]$} & {$[0.9227]$} & {$[0.4692]$} & {$[0.8802]$} & {$[0.6625]$} & {$[0.5496]$} & {$[0.4765]$} & [0.9282] & {$[0.9282]$} & {$[0.5989]$} & {$[0.9029]$} & [0.8694] \\
\hline
\end{tabular}

Notes: AT, BE, FI, FR, GE and NL stand for Austria, Belgium, Finland, France, Germany and the Netherlands respectively, while $h d$, $c d$ and $p d$ stand for household, corporate and public debt respectively.

See Appendix 1 for a definition of the variables and the text for the specification of the estimated model.
In the ordinary brackets below the parameter estimates, the corresponding t-statistics are shown, based on the small-sample degree of-freedom corrected, heteroskedasticity and autocorrelation consistent standard In the ordinary brackets below the parameter
errors proposed by Newey and West (1987).

$\chi^{2} \mathrm{~N}, \chi^{2} \mathrm{sc}$ and $\chi^{2} \mathrm{H}$ are the Jarque-Bera test for normality, the Breusch-Godfrey LM test for second-order serial correlation and the Breusch-Pagan-Godfrey test for heteroskedasticity. The associated probability values are given in square brackets. 